San Jose State University

SJSU ScholarWorks

Master's Projects

Master's Theses and Graduate Research

Spring 2019

\title{
Walk n' Roll (WnR) San Jose: An Initiative to Promote Active Transportation and Safe Routes to School for Children in San Jose, California
}

François Xavier Hans Voltaire

San Jose State University

Follow this and additional works at: https://scholarworks.sjsu.edu/etd_projects

Part of the Education Policy Commons, Health Policy Commons, Policy Design, Analysis, and

Evaluation Commons, Public Administration Commons, and the Transportation Commons

\section{Recommended Citation}

Voltaire, François Xavier Hans, "Walk n' Roll (WnR) San Jose: An Initiative to Promote Active Transportation and Safe Routes to School for Children in San Jose, California" (2019). Master's Projects. 729.

DOI: https://doi.org/10.31979/etd.685m-d5d3

https://scholarworks.sjsu.edu/etd_projects/729

This Master's Project is brought to you for free and open access by the Master's Theses and Graduate Research at SJSU ScholarWorks. It has been accepted for inclusion in Master's Projects by an authorized administrator of SJSU ScholarWorks. For more information, please contact scholarworks@sjsu.edu. 


\section{Walk n' Roll (WnR) San Jose:}

An Initiative to Promote Active Transportation and Safe Routes to School for

Children in San Jose, California

by

François Xavier Hans Voltaire

A Thesis Quality Research Project

Submitted in Partial Fulfillment of the

Requirements for the

Master's Degree

in

PUBLIC ADMINISTRATION

Prof. Frances Edwards, Ph.D.

Adviser

The Graduate School

San Jose State University

Spring, 2019 


\section{TABLE OF CONTENTS}

BACKGROUND

PuRPose OF STUdY

Problem STATEMENT

WALK N' ROLL (WNR)

SAFE ROUTES TO SCHOOL (SRTS)

VISION ZERO

ACTIVE ANd Public Transport in Road Safety

SPEED AND HEALTH

FINDINGS

STRATEgIES/TECHNIQUES TO DELIVER SERVICES 22

WNR PARTICIPATING SCHOOLS

SCHOOLS WITH THE HIGHEST WNR SUCCESS RATE

Emissions SAVings Evaluation fOr SCHOOLS GA, ED, DG, AND CH

71

SCHOOLS WITH THE LEAST WNR SUCCESS RATE

Schools With High Active Transportation/High Mode Shift \% 


\section{BACKGROUND}

\section{Purpose of Study}

How effective is the Walk n' Roll (WnR) program in promoting active transportation near school zones in San Jose, California? The intent of this research question is to discern the effect of the City of San Jose's WnR program in encouraging children to actively travel to school (walking/cycling) and using other means such as scooters and skateboards. This research will use data from 2012-2018 to measure the efficacy of the program. This project strives to discover whether the tools and strategies that the program is using impact the augmentation level of the number of students who actively travel and transport to school.

\section{Problem Statement}

Nowadays, less than $15 \%$ of children in the United States actively commute (walk/bike) to school, compared to $60 \%$ who lived within a 2-mile radius of a school 30 years ago (CalTrans Division of Local Assistance, 2018). More than 50\% of children who live in the country are driven to or from their institution in vehicles. According to research by CalTrans (2018), more than $20 \%$ of children living in the United States are considered overweight or obese compared to only $5 \%$ in the past.

Authorities believe that these statistics are pointing to a rise in childhood diseases that are preventable, missed opportunities for children to grow into self-reliant and independent adults, and worsening air quality and congestion within school zones. Advocates argue that organizations need to develop and fund more programs that support safety and efforts to promote active transportation to school for children within a collaborative community framework (CalTrans Division of Local Assistance, 2018). 


\section{WnR}

The City of San Jose's Department of Transportation implemented WnR San Jose in 2012 (Street Smarts, 2014). The goals of the program are to increase walking and biking to school, ease traffic congestion and related air pollution, create a safer environment within school zones and foster a healthy and active lifestyle for children. The program is funded by the Metropolitan Transportation Commission, and it was founded to improve the safety of pedestrians and bicyclists near schools, the health and overall physical fitness of children, and the infrastructure near school zones to promote active transportation (Street Smarts, 2014).

The WnR program focuses on five main components to achieve its goals: education, encouragement, engineering \& evaluation, and enforcement (Street Smarts, 2014). The elements are used to instill healthy and active lifestyle behaviors by encouraging daily physical activities in a safe and social environment. The program strives to engage school and local officials, students, and community members to develop and build a strong sense of community (Street Smarts, 2014).

\section{Education}

The program uses activities such as safety assemblies, bike rodeos, and walk-a-thons to promote active transportation safety. The city provides pedestrian and bicycle safety tips to students and parents to increase their awareness. The program has a partnership with Vision Zero San Jose and Street Smarts. Vision Zero San Jose is an initiative that was adopted in 2015 to eliminate injuries and fatalities that are caused by traffic collisions (City of San Jose's Department of Transportation, 2018). Street Smarts is a program that focuses on traffic safety education to address drivers', pedestrians', and bicyclists' behaviors (Street Smarts, 2014). The city uses and combines all three programs to inform residents about safe human behaviors, and how elements 
such as education, engineering, and enforcement are essential in promoting a safe transportation system for citizens.

Safety assemblies are incorporated into the City of San Jose's Street Smarts program (Street Smarts, 2014). Assemblies are fun and interactive presentations that foster pedestrian/bicycle safety. Street Smarts assemblies are usually 35-40 minutes long, and they are conducted at the main stage area of schools (Street Smarts, 2014). Many schools prefer to split their safety presentations into two groups by grade level, dividing the K-3 and 4-6 grades. Schools favor that strategy because it better accommodates students in understanding the curriculum of the presentations that are being demonstrated (Street Smarts, 2014).

The city sponsors bike rodeo events for all participating schools. City staff strive to teach children how to properly and safely ride their bicycles in a controlled and safe environment (Street Smarts, 2014). The bike rodeos are offered through the city's Street Smarts program. Rodeo events are usually during or after school, and they typically last one hour (Street Smarts, 2014). The city provides helmets at no cost to children who do not possess one during all rodeo events (Street Smarts, 2014). The city carries a bike blender to rodeo events to reward children for their participation. Children are able to ride and blend smoothies during the events. Schools are responsible for providing frozen fruits and juices (Street Smarts, 2014).

\section{Encouragement}

The city coordinates activities such as walking school buses, bike to school day, and special events such as Monthly and International Walk to School Day to encourage students to walk and bike (Street Smarts, 2014). City staff assist school officials and parents in organizing all the events to ensure that schools are successful in participating. International Walk to School Day is one of the program's major events. The event occurs annually in October, and it is part of a 
global effort to celebrate the benefits of walking and biking to school and reducing greenhouse gas emissions. The city uses the occasion to promote civic engagement by allowing all city staff members to participate and help schools in hosting the event (Street Smarts, 2014).

To promote cycling to school, the WnR program partners with the City of San Jose's Active Transportation program to provide bicycle racks for public schools in San Jose (Street Smarts, 2014). Due to a limitation in supply, requests from participating schools are granted on a first-come, first served basis. Racks are shaped similar to an upside-down U letter, and they are made of flat-finish and rust-resistant galvanized steel (Street Smarts, 2014). After installations, students are able to park their bicycles parallel to the racks, with one bike on each side. Each rack accommodates two bikes, and students are responsible for carrying their own locks to secure their bikes (Street Smarts, 2014).

The WnR program sponsors a poster contest for all new participating schools. The city encourages students at all grade levels to submit creative artworks that advertise the health and environmental benefits of walking and bicycling to school (Street Smarts, 2014). Posters can be developed individually by students or jointly with other classmates. WnR staff are responsible for providing schools with the materials that they need to design their posters. In addition, the city funds a 4' x 8' vinyl banner for schools to display on their campuses to promote WnR (Street Smarts, 2014). The city collaborates with all participating schools to determine which posters will be selected to represent the visual graphic of the program (Street Smarts, 2014). Typically, schools are responsible for selecting the three-best graphics from their students, then staff members throughout the Department of Transportation determine which poster is the best representation of $\mathrm{WnR}$.

\section{Engineering \& Evaluation}


The city uses grant funds that already exist and city funds to address high priority needs for this component of the WnR program (Street Smarts, 2014). The program uses a community-based approach to identify locations where improvements are needed in areas near school zones. This process allows the city to enhance walking and biking routes to school for students (Street Smarts, 2014).

The city primarily conducts walk audits to help schools enhance their suggested walking routes. WnR staff oversee the process of recruiting parents and community members who are familiar with the routes to conduct the audits (Street Smarts, 2014). The primary responsibility for recruited individuals is to document observed conditions that hinder safe walking and biking options for students. Examples of these concerns include street lighting, sidewalk width and conditions, missing sidewalks, American with Disabilities Act (ADA) ramps, trash and debris, and traffic volume (Street Smarts, 2014). After recruited volunteers document and send their concerns regarding walking/biking conditions throughout school zones to the city, local staff officials investigate the problems, and where appropriate, propose recommended solutions (Street Smarts, 2014). Sometimes, the city is able to implement some of its recommended solutions within existing grant funds; however, others may require the city to seek additional grant funding (Street Smarts, 2014).

The process of a walk audit is conducted over the course of several months (Street Smarts, 2014). WnR staff are responsible for providing training to all participating schools during their first walk audit. For schools that have more than one route, the program allows volunteers and/or parents to conduct walk audits without the supervision of city staff (Street Smarts, 2014). After the completion of all walk audits, the school's WnR committee is responsible for delivering a brief summary report to their WnR staff liaison for review. The city 
requires a final walk audit report with the inputs of volunteers and parents from WnR staff to proceed to the next phase of the walk audit process. WnR staff oversee the process of compiling all gathered information to complete the final walk audit report. This process is essential because it serves as the basis for what city engineers will need to adequately investigate the concerns of parents and volunteers.

\section{Enforcement}

The WnR program collaborates with the San Jose Police Department's (SJDP) Operation Safe Passage and the Department of Transportation's (DOT) Parking and Traffic Compliance team to promote safety near school zones (Street Smarts, 2014). SJPD's Safety and Education unit helps all participating WnR schools in establishing and certifying school safety patrols (City of San Jose's Police Department, 2018). DOT's Parking and Traffic Compliance team is responsible for enforcing posted parking regulations near school zones in an effort to improve compliance with local and state parking regulations (City of San Jose's Department of Transportation, 2018).

Both units assist WnR in promoting safety near school zones for children when they are using crosswalks, crossing intersections and walking on narrow high-volume roadways (City of San Jose's Department of Transportation, 2018). The intent of this partnership with both units for WnR is to assist children in safely crossing streets and intersections to and from schools, so that students and their parents feel safe when they are walking/biking. SJPD's School Safety and Education unit is responsible for providing training, guidance, and supervision to student safety patrols (Street Smarts, 2014).

SJPD supports participating WnR schools by inspecting and evaluating their student safety patrol programs. The School Safety and Education program manager oversees the unit, and it consists of three supervisors (City of San Jose's Police Department, 2018). The 
supervisors are responsible for providing crossing guards and outreach to all participating schools (Street Smarts, 2014). Moreover, the primary responsibilities of DOT's Parking and Traffic Compliance team are to help schools ease speeding violations, traffic congestion, and eliminate illegal parking by parents when they are not obeying posted parking regulations and speed limit signs (City of San Jose's Department of Transportation, 2018). 


\section{LITERATURE REVIEW}

Numerous studies demonstrate that walking and bicycling to school allow children to be physically active. Both alternatives have been proven to be effective in helping children in reducing their risk of being obese and suffering from diabetes (Law \& Policy Innovation, 2018). One of the primary goals for public health in the United States and globally is to improve the level of physical activity for all individuals (U.S. Department of Health and Human Services, 2017). Walking and biking are two of the most common forms of physical activity. Both options are referred to as transportation physical activity or active transport, when people walk or bike to travel from one location to another (Nicholson et al., 2014). Children are more likely to be engaged during school activities and achieve greater academic achievements when they exercise or participate in other forms of active behaviors before going to school (Larouche, Mammen, Rowe, \& Faulkner, 2018).

Physical activity is a key determinant of energy expenditure, and it is fundamental to energy balance and weight control (World Health Organization, 2018). People who are insufficiently active physically have a 30 percent increased risk of all-cause mortality compared to individuals who engage in at least 150 minutes of moderate intensity physical activity per week (Nicholson et al., 2014). Insufficient physical activity is one of the 10 leading risk factors for global mortality (World Health Organization, 2018). Research by Nicholson et al. (2014) states that the prevalence of insufficient physical activity is highly correlated to people's income level and their residential location.

Children and adolescents who engage in at least 60 minutes of moderate to vigorous intensity physical activity daily have higher levels of cardiorespiratory fitness, muscular endurance and strength compared to their inactive peers (World Health Organization, 2018). 
Globally, 81 percent of school going adolescents aged 11-17 years were insufficiently active physically in 2010 (Nicholson et al., 2014). School going adolescent girls are more likely to be less active compared to boys (Nicholson et al., 2014). Physical activity is beneficial because it can help children and adolescents in reducing symptoms of anxiety and depression (Wojan \& Hamrick, 2015).

Research by Buttazzoni, Coen, and Gilliland (2018) argues that factors such as distance to school, child age, and gender are elements that impact the probability of children walking and biking to school. The authors explain that social concerns such as stranger danger, bullying and the perceptions of traffic safety influence the rate of children in active transportation. Panter, Jones, Sluijs, and Griffin (2009) indicated that block density, signalized intersections, and street trees are additional factors that are linked to the rate of active school travelers.

Based on evidence from the United States and Australia, positive perceptions of the environment, shorter journey distance, and social support increase the rate of children who actively commute to school (Active Living Research, 2011). Children are more likely to walk and bike to school if one or both of their parents actively commute to work. Research by Ross, Rodriguez, and Searle (2017) supports that attitudinal, social, and environmental factors, such as parental encouragement and concerns about traffic safety, impact the prevalence of children in active commuting behaviors. The authors noted that the likelihood of parents allowing their children to actively travel to school is moderated by the association of attitudinal and environmental factors.

Buttazzoni et al. (2018) state that successful active transport programs are based on the structure of their plan and the influence of their features of efficacy and sustainability. The authors talked about the importance of measuring a school's capacity before implementing a safe 
travel plan program to its priorities. They stated that administrators who oversee active transport programs must first determine whether or not schools will have the capacity to be internally stable, or will they need significant support externally to establish a successful active transport plan (Buttazzoni et al., 2018).

Research by Panter et al. (2009) claims that most active travel plans are usually ineffective because schools' administrators are unable to balance other workloads with overseeing active transport programs. In addition, schools can be unsuccessful with launching an active transport program when they are not receiving enough help from external stakeholders (Buttazzoni et al., 2018). It is rare or impossible for safe transport plans to be effective when school officials do not have engaged relationships with their external stakeholders. According to Panter et al. (2009), external stakeholders must support schools in providing promotional items and other necessary resources for implementing a successful active transportation program. Panter et al. (2009) mentioned that the work combination of both school and local officials is essential for effective active transport plans. The authors argue that identifying and subsequently building safe transport plan committees can help schools internalize motivation for active school transportation.

\section{Safe Routes to School (SRTS)}

Many parents do not support their children in walking and cycling to school because they feel that their child's institution neither encourages nor discourages active transportation (Chaufan, Yeh, \& Fox, 2012). According to findings from Chaufan et al. (2012), parents' willingness to allow or prevent their children to walk or bike to school depends on safety and convenience concerns. High traffic speeds, unsafe intersections and crossings, violence or crime along routes, crossing guards, lack of sidewalks or pathways, and lack of walking school buses are the main 
issues relating to safety concerns that discourage parents from allowing their children to actively commute to school (Mcdonald et al., 2016).

Chaufan et al. (2012) state that some of the convenience concerns for parents are long commuting distance, weather or climate, the impact of active transport on children before and after school activities, and the convenience of driving. Based on a survey that was conducted in the United States, the same percentage (50\%) of parents who agreed that they would allow their children to actively commute to school if their concerns were being addressed also disagreed that they would permit their kids to walk or cycle to school alone (Chaufan et al., 2012).

Motor vehicle crashes are the leading cause of death for children aged 8 to 19 years old in the United States (Muennig, Epstein, Li, \& DiMaggio, 2014). Muennig et al. (2014) found that vehicle crashes were also the second leading cause of death for children aged 4 to 7 years old. The authors argue that the country should invest more in roadway safety, even though the probability of a child being severely injured in any given intersection is marginal. The United States enacted SRTS in 2005 to build new sidewalks and bicycle lanes, improve safety at crossings, upgrade signage, and enhance pedestrian education (Muennig et al., 2014).

The SRTS program was established under the federal Safe, Accountable, Flexible and Efficient Transportation Equity Act - a Legacy for Users (SAFETEA-LU) in 2005 (Muennig et al., 2014). The initiative was a $\$ 612$ million-dollar program that funded state departments of transportation (Muennig et al., 2014). The intent of SRTS was to reduce important barriers to commuting without vehicles and encourage children to walk and bike to school by making active transportation safer. In the United States, capital improvement projects were funded at 10,400 schools (Muennig et al., 2014). After 2011, Congress decided to enact Moving Ahead for Progress in the $21^{\text {st }}$ Century (MAP-21; Pub L No. 112-141) to replace the SAFETEA-LU 
(Muennig et al., 2014). Muennig et al. (2014) stated that this transition led to an end to funding for SRTS. The authors confirmed that SRTS can continue under discretionary funding at the state and local level (Muennig et al., 2014).

\section{Vision Zero}

In 1997, the Swedish parliament enacted Vision Zero; a bill that strives to ameliorate the rate of fatalities and serious injuries within the road transport system (Johansson, 2009). Vision Zero was established around the basic idea that even if not all crashes or collisions can be avoided, all severe injuries can, in principle, be prevented (Johnston, 2010). Vision Zero is a long-term goal for the design and functioning of the road transport system. Johansson (2009) states that the designers of the system are responsible for the design, operations and use of the transport road system. Designers oversee the level of safety within the entire system, and road users are responsible for following the rules set by the designers (Johansson, 2009). Vision Zero focuses on human life and health in the design and functioning of the road transport system.

The Vision Zero system uses a variety of strategies such as refining traffic infrastructure, increasing space for vehicles and pedestrians, and managing kinetic energy in crashes and collisions (Johansson, 2009). Johansson (2009) confirms that kinetic energy is what kills and injures road users- not accidents. The author explained that an error tolerance can be built into the traffic system. Research by Johnston (2010) found that kinetic energy can be controlled by managing crashes in terms of the energy that is transferred to the human body. Johnston (2010) explains that designers focus on not exceeding the human tolerance when designing and constructing traffic systems. According to Johansson (2009), this tolerance is a given factor, and it cannot be affected to any significant extent. He confirmed that if pedestrians are hit by vehicles that are traveling at $25-30 \mathrm{~km} / \mathrm{h}$, most people will survive after the accidents. However, 
Johansson stated that if vehicles are instead traveling at $50 \mathrm{~km} / \mathrm{h}$, most pedestrians will be killed if they are hit by the cars (Johansson, 2009).

The management of kinetic energy in crashes and collisions is formulated into two principles: integration and separation (Johansson, 2009). Kinetic energy is managed by integrating compatible traffic elements and separating those that are incompatible. The system consists of numerous boundary values, such as vulnerable road users should not be exposed to motorized vehicles at speeds exceeding $30 \mathrm{~km} / \mathrm{h}$, car occupants should not be exposed to other motorized vehicles at speeds exceeding $50 \mathrm{~km} / \mathrm{h}$ in 90 degree crossings, and car occupants should never be exposed to oncoming traffic at speeds exceeding $50 \mathrm{~km} / \mathrm{h}$ if oncoming vehicles are considerably different sizes (Johansson, 2009). Research by Johansson (2009) found that designers should never mix vulnerable road users and cars at speeds exceeding $30 \mathrm{~km} / \mathrm{h}$. Johansson claimed that designers should always separate vulnerable road users from cars when speeds are higher (Johansson, 2009).

\section{Vision Zero San Jose}

The City of San Jose implemented Vision Zero in May 2015 (City of San Jose's Department of Transportation, 2018). San Jose's Vision Zero plan identifies a series of actions centered on enhancing efforts related to education, engineering, and enforcement. The City of San Jose's goal is to decrease the rate of residents driving to their destinations from $80 \%$ today to $40 \%$ by 2040 through the adoption of the Envision San Jose 2040 General Plan (City of San Jose's Department of Transportation, 2018). The city intends to design roadways in a manner that accommodates safe active transportation for pedestrians and bicyclists. The city describes its plan as designing and constructing complete streets throughout all roadways in San Jose. Complete streets will provide safe, comfortable, attractive, and convenient access and travel for 
pedestrians, bicyclists, motorists, and transit users of all ages, abilities, and preferences (City of San Jose's Department of Transportation, 2018).

The City of San Jose adopted Bike Plan 2020 to promote cycling and make it an integral part of daily life for San Jose residents (City of San Jose's Department of Transportation, 2018). The goals of Bike Plan 2020 are to complete a 500-mile bikeway network (400 miles on-street and 100 trail miles), achieve 5 percent of all trips taken by bike, decrease the rate of bike collision by 50 percent, and add 5,000 bike parking spaces throughout the city (City of San Jose's Department of Transportation, 2018). San Jose is managing ongoing engineering, educational and enforcement initiatives aimed towards achieving these goals (City of San Jose's Department of Transportation, 2018).

\section{Active and Public Transport in Road Safety}

Research by May, Tranter, \& Warn (2011) states that active transport modes and public transport usage deserve closer analysis in terms of how they can become part of road safety strategies, how their uptake can be facilitated, and what kind of limitations that are typically applied. The authors argue that even though pedestrians and cyclists are legitimate road users, they are frequently overlooked in the system of urban transportation that is shaped by the dominance of motorized vehicles. May et al. (2011) agreed that the landscape of the environment is closely associated with active transport modes. The authors noted that communities with walkable infrastructure tend to have higher measures of community health and higher levels of interaction and social capital (May et al., 2011).

May et al. (2011) support the encouragement of public transport usage because of its environmental benefits, and they argue that freeway expansion is environmentally harmful and likely to be disadvantageous for road safety. The authors elucidated that public transport is 
beneficial because it supports congestion management, social inclusion, and energy security. Mees, O'Connell, and Stone (2008) suggest that policy and funding priorities need to be directed away from urban motorways towards more environmentally friendly modes, such as public transport, cycling, and walking. The authors believe that there needs to be a reorientation of road space and rules to give pedestrians priority over motor vehicles. Vadeby and Forsman (2018) believe that forward-thinking political leaders and politically active citizenry are needed to demand better options for safe and sustainable transportation, as well as programs that address climate change and peak oil.

\section{Speed and Health}

Research by Tranter (2010) argues that speed is most commonly seen as a health problem in relation to road crashes. Tranter (2010) indicates that high car speeds can negatively impact the level of physical activity through reductions in active transport, including children's independent mobility. Numerous studies have proven that when there is an increase in speed for motorized traffic, the levels of pollution usually escalate. Research by Tranter (2010) found that high speed transport encourages urban sprawl and the loss of agricultural land and market gardens. In addition, Tranter (2010) proclaims that the risk of pedestrian death in crashes rises from 5 percent at $20 \mathrm{mph}$ to 45 percent at $30 \mathrm{mph}$ and 85 percent at $40 \mathrm{mph}$.

One kilometer per hour $(1 \mathrm{~km} / \mathrm{h})$ in traffic speed can lead to a 3 percent increase in injury crashes and a 4-5 percent increase in fatal crashes (Tranter, 2010). Many comparisons between the risks associated with speeding and driving under the influence of alcohol and drugs have been demonstrated and analyzed. According to Tranter (2010), the risk of injuries from a collision for an individual driving at the speed limit with a blood alcohol level of $0.05 \mathrm{~g} / 100 \mathrm{ml}$ is similar for a person driving $5 \mathrm{~km} / \mathrm{h}$ over a $60 \mathrm{~km} / \mathrm{h}$ speed limit. Tranter (2010) argues that in 
addition to speeding being a key factor in accident involvement, attitudes to speeding have been linked with accident involvement. 


\section{METHODOLOGY}

\section{Research Description}

Research from this paper applied the model of process evaluation from Program Planning and Evaluation for the Public Manager by Ronald and Kathleen Sylvia (2012). The reason for using the process evaluation model was to determine the effectiveness level of the City of San Jose's WnR program in delivering services with its current techniques. The program is an initiative that the city established in 2012, to increase the number of children who walk and cycle to school. The program's main focus is to promote active transportation near school zones, educate children, parents, school officials, and community members about traffic safety, and provide the necessary tools and resources that school communities throughout San Jose will need to support active transportation. The effectiveness of the $\mathrm{WnR}$ is measured through the program's student tally data approach that monitors the number of children who actively commute to school.

Research from this project focused on measuring the top 10 schools with the highest active transportation and mode shift percentage and the lowest 10 schools with the least children who actively commuted to school during the Fall of 2018. This paper classified both the top 10 and the lowest 10 schools into their own category. This research categorized the schools that were able to be classified under both sections, high active transportation percentage/high mode shift level schools and low active transportation percentage/low mode shift level schools to analyze the tools and strategies that they were using to champion the program.

This research used the findings to investigate the reasons why schools were successful or unsuccessful in developing students into active commuters. Additionally, further information regarding the measurement of the program (emissions savings from high active transportation percentage/high mode shift level schools) was provided in the Findings section of this paper. 
This project orchestrated the findings of this research to develop alternatives in the analysis section that correspond to efficiency and sustainability for the program. The purpose of this step was intended to promote service delivery enhancement and improve the rate of satisfaction for participating schools enrolled in the program.

\section{Data}

Data collected included student tally information between 2012 and 2018 from the City of San Jose's WnR program. Student tallies provided rigorous measures that corresponded to the number of students who were enrolled in school and the number of students who walked to school. The tallies included the number of children who cycled, and the number of students who used means such as school buses, family vehicles, carpool, and transit, and other active alternatives such as skateboards and scooters to travel to school. Student tallies were used to generate robust graphic visuals that thoroughly explicate the numbers that were collected from the tally surveys.

Student tally surveys are a required component for all participating WnR schools. Participating schools are required to conduct the tallies twice per school year (Fall/Spring). The surveys encompass questions such as how students arrived at school and how do they plan to leave for home after school. Teachers are responsible for conducting the tallies, and WnR staff typically provide trainings for schools that have trouble gathering their data. The student tally feature of the program is essential because it permits WnR staff to measure whether schools are meeting the required performance goal that is set by the city; all WnR participating schools must achieve and retain a $20 \%$ mode shift percentage after their benchmark student tally measure. The mode shifts for participating schools are calculated by dividing the deduction result of current 
period percentage and baseline percentage to baseline percentage. Example: Mode Shift $=$ Current Period Percentage - Baseline Percentage / Baseline Percentage.

The intent for using the process evaluation model was to discern how the program's outcome and impact were achieved. One focus of this research was to analyze the quantity of resources and services that were delivered to the schools that corresponded to a high active transportation percentage/high mode shift level and low active transportation percentage/low mode shift level. This approach was beneficial because it provided a meticulous analysis that was used to assess the infrastructure process of the participating schools to evaluate their capacity in achieving and maintaining a $20 \%$ mode shift percentage. 


\section{FINDINGS}

\section{Strategies/Techniques to Deliver Services}

The WnR program uses a wide range of techniques throughout the year to help participating institutions in integrating WnR into their curriculum. WnR staff are responsible for ensuring that schools receive the help that they need to manage events, duties, and activities on a monthly basis. The program provides a toolkit that schools can use to organize WnR events by months. City staff members encourage school officials to use this tool because it includes essential resources and materials that they can incorporate into their general plan (Street Smarts, 2014). Table one demonstrates a typical year plan for participating WnR schools. 
Table 1: WnR Year Plan

\begin{tabular}{|c|c|}
\hline September & $\begin{array}{l}\text { - } \text { Conduct student tallies and parent surveys } \\
\text { - } \quad \text { Prepare to celebrate International Walk to School Day }\end{array}$ \\
\hline October & $\begin{array}{l}\text { - Recruit Walk n’ Roll champions/volunteers } \\
\text { - Establish Walk n' Roll committees and develop school work plans } \\
\text { - Schedule Street Smarts safety presentations } \\
\text { - Celebrate International Walk to School Day }\end{array}$ \\
\hline November & $\begin{array}{l}\text { - } \quad \text { Establish suggested walking and biking routes } \\
\text { - } \text { Organize regular walk/bike to school day events }\end{array}$ \\
\hline December & - Organize walking school buses/bike trains \\
\hline January & $\begin{array}{l}\text { - } \text { Conduct walk audit } \\
\text { - Submit results to San Jose's Department of Transportation }\end{array}$ \\
\hline February & - Develop school safety patrol at school sites \\
\hline March & - Expand Walk n' Roll committee at school sites \\
\hline April & - Assess the impact and outcomes of the program at school sites \\
\hline May & $\begin{array}{l}\text { - } \text { Organize bike to school day events } \\
\text { - Hold bike rodeo event at school sites }\end{array}$ \\
\hline June & $\begin{array}{l}\text { - Celebrate outcomes of the program at school sites } \\
\text { - Recognize leaders, get organized, and get inspired }\end{array}$ \\
\hline
\end{tabular}

Source: Street Smarts, 2014 


\section{September}

Every September, WnR staff members prioritize three primary elements: student tallies, parent surveys, and preparing for the celebration of International Walk to School Day. WnR staff help schools gather data on their current walking and biking rates. This process is important because it allows schools to track their active transportation rate throughout the school year. The city is responsible for providing school tally and survey forms to collect their information. WnR staff members are responsible for overseeing the administrative and publication duties that relate to International Walk to School Day during this month. Staff members are responsible for ensuring that International Walk to School Day publications are designed in alignment with the mission of the event and are distributed to participating schools in a timely manner (Street Smarts, 2014).

\section{Student Tallies}

The data collection process of the program is essential because it helps school officials and city staff understand the walking and biking culture of students. The city has established a simple method that allows teachers at participating WnR schools to easily gather their information. WnR staff provide student tally forms to participating schools at the beginning and end of every school year. The tallies allow schools to establish a baseline against which they can measure their progress (Street Smarts, 2014). See the next page for an example of the student tally form that the program uses. 


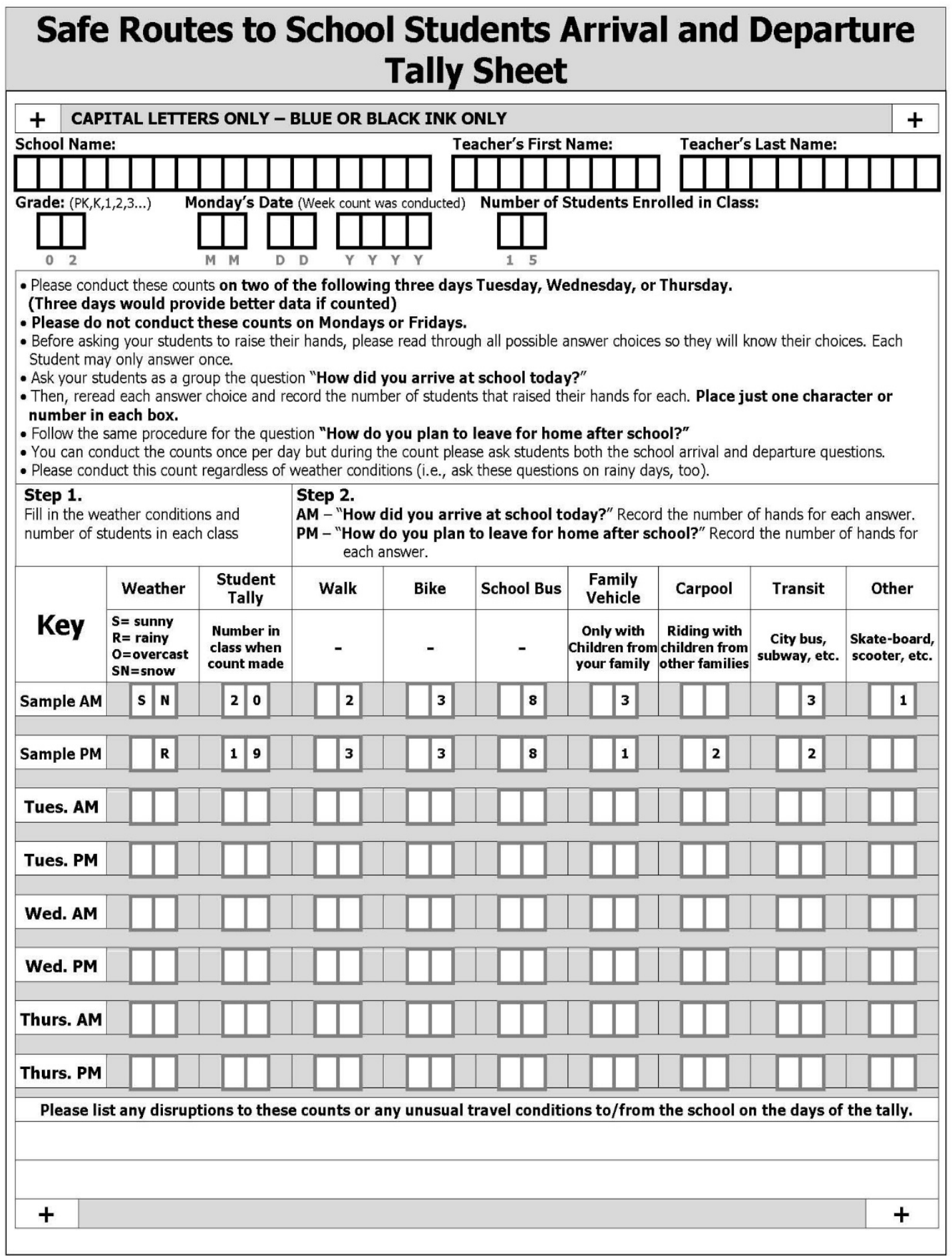

Source: Street Smarts, 2014 
The form is used to record the number of students on a particular day who walked or traveled to and from school by bike, bus, or car. Schools are required to conduct the tallies on three consecutive days in the middle of a single week. This method is essential because it provides accurate student travel modes. The tallies are required to be conducted by a teacher or parent/volunteer. The city uses the tally measures to establish travel patterns, estimate traffic congestion, and calculate emissions savings by schools (Street Smarts, 2014).

Often times, students are tempted to raise their hands for more than one travel method during the collection process. WnR staff usually suggest that teachers or volunteers to write the number of responses for each travel method on the classroom's board, and make sure that the total adds up to the total number of students in the classroom. Another technique that WnR staff recommend to teachers/volunteers is room separation. WnR staff support teachers/volunteers to separate students on different sides in their classroom based on a particular method of transportation that students use to travel to school. Both strategies are beneficial because they help teachers/volunteers to not double-count students. WnR staff require teachers/volunteers to report the longest travel mode that students use to get to school if they used more than one means. For example, a student who biked 1-mile to a city bus to travel 0.5 -mile to school, would need to be reported as "biked to school" on the tally form (Street Smarts, 2014).

\section{Parent Surveys}

Schools are required to participate in a parent survey when they are entering and exiting the WnR program. The surveys must be completed by parents and/or guardians. The purpose of the survey is to gather information that corresponds to the perceptions and concerns that parents and guardians have about their children walking/cycling to and from school. WnR staff are responsible for processing and analyzing the surveys. The surveys collect information about the 
feelings and attitudes that parents have or experience about their children when they are walking and biking to school (Street Smarts, 2014).

WnR staff provides various tips to parents for completing the surveys successfully. They encourage parents to thoroughly read every question and urge them to seek the guidance of committee volunteers if something does not make sense (Street Smarts, 2014). Parent Surveys must be filled in clearly with blue or black ink. The city requires parents to only enter information regarding their child/children who attend a participating WnR school where they receive the surveys (Street Smarts, 2014). For instance, if a parent receives a survey from School A, but has another child who attends School B, he/she is required to only record information on the survey about the child who goes to School A. See the next two pages for an example of the parent survey form that the program uses. 


\section{Figure 2: WnR Parent Survey, Page 1}

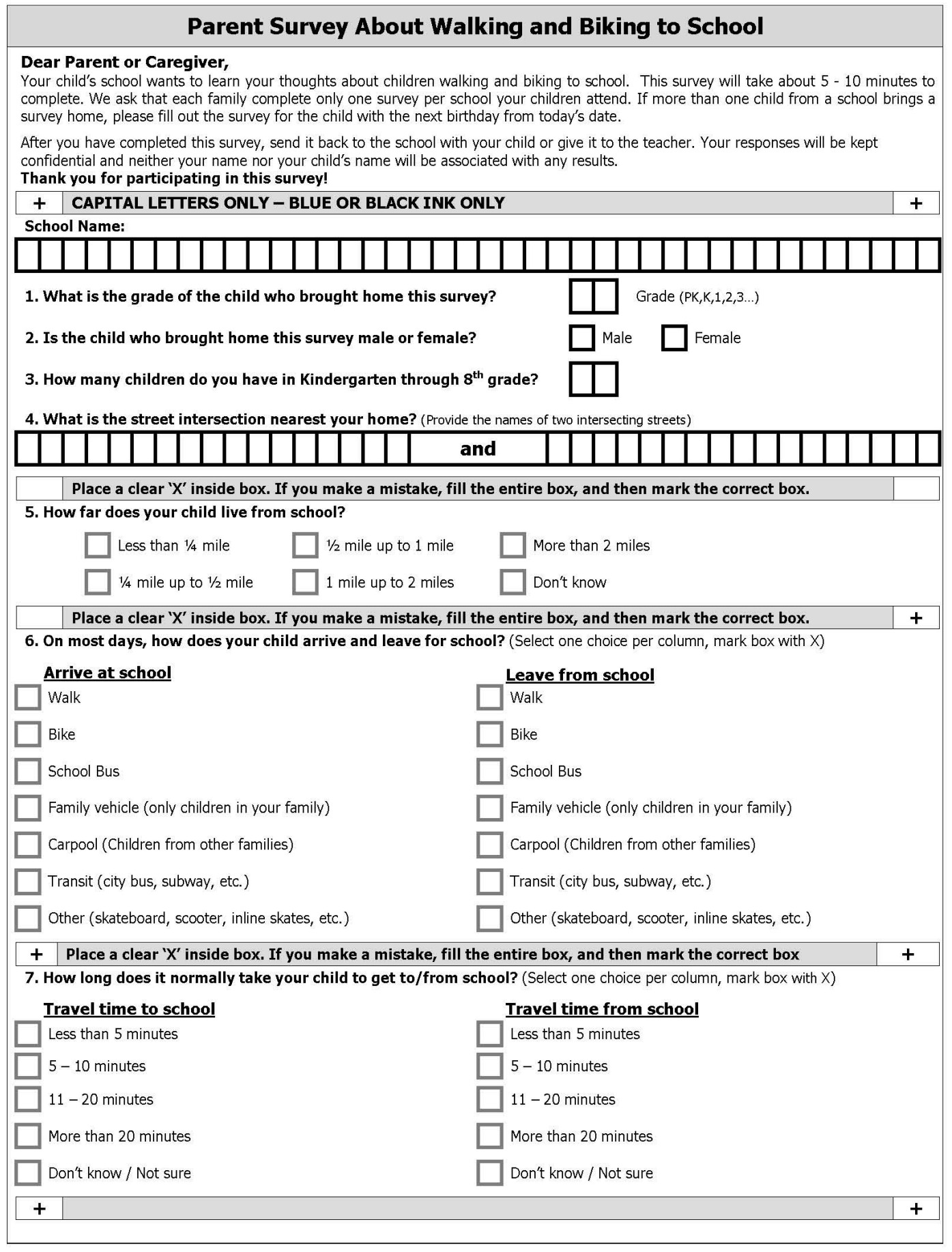

Source: Street Smarts, 2014 


\section{Figure 2: WnR Parent Survey, Page 2}

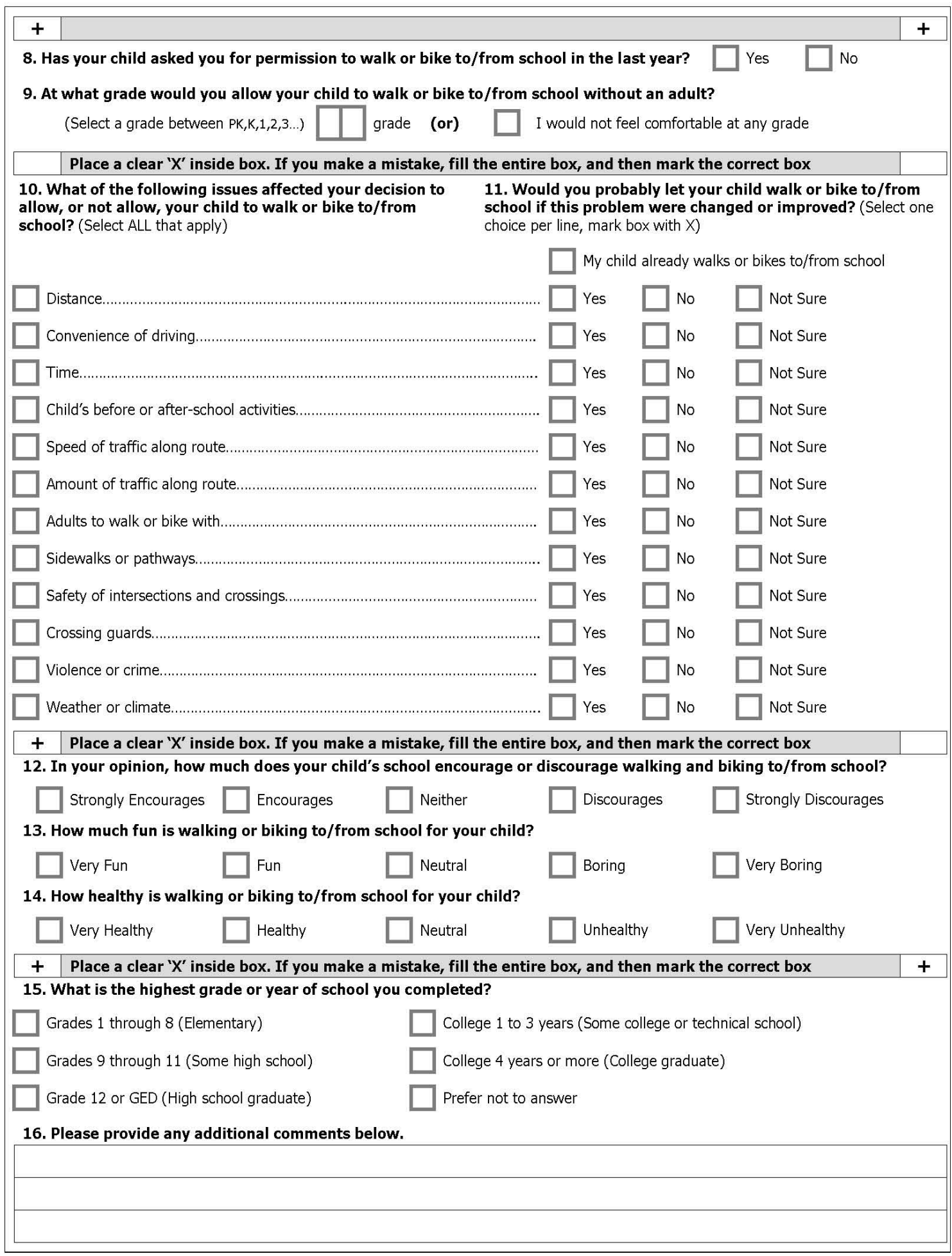

Source: Street Smarts, 2014 


\section{International Walk to School Day}

This event was implemented after the establishment of Walk to School Day. The Partnership for a Walkable America created Walk to School Day in the United States in 1997 (Street Smarts, 2014). Soon after, the U.S. joined forces with Canada and Great Britain to establish International Walk to School Day. Throughout the U.S., the National Center for Safe Routes to School serves as the national coordinating agency for Walk to School activities. The National Highway Traffic Safety Administration, Safe Kids Worldwide, the Centers for Disease Control and Prevention, the Federal Highway Administration, and the U.S. Environmental Protection Agency are some of the major organizations that support International Walk to School Day in the U.S.

\section{October}

This month includes four main components for the WnR program: Recruiting WnR Volunteers, Building WnR Committee and Developing School Work Plans, Scheduling Street Smarts Safety Presentation, and Celebrating International Walk to School Day. WnR staff are responsible for helping schools in recruiting volunteers and training members about the culture of the program. WnR staff encourage participating schools to establish a committee because it has been proven that it is the best way to organize and achieve the efforts of the program's goals (Street Smarts, 2014).

\section{Building WnR Committee}

To assist schools in building a committee, WnR staff participate in a variety of events, such as back to school night, movie nights, picnics, and many other occasions to help schools recruit volunteers (Street Smarts, 2014). The role of the WnR committee is to lead and coordinate the program. The committee is responsible for establishing specific walking/biking goals and organizing members and other logistics that are necessary to implement the program. Volunteers 
can be parents, school administrators, PTA/PTO representatives, principals, teachers, and student councils (Street Smarts, 2014).

WnR staff encourage committees at participating schools to prioritize flexibility for their members. It has been proven that the program successfully effectuates throughout communities when committees are flexible and allow their members to work jointly or separately, depending on the needs of the groups. WnR staff urge committees to review the purpose and benefits of the program before establishing their community goals. This practice is recommended to committees because it can help members in framing their work plan specifically and appropriately. This process is essential because it will allow committees to develop appropriate ideas for programs and activities that will best fit their school's needs (Street Smart, 2014). The following tables provide a list of some of the possible $\mathrm{WnR}$ committee roles and responsibilities.

Table 2: Program Facilitators - School/School District Representatives

\begin{tabular}{|c|ll|}
\hline & $\begin{array}{l}\text { - To politically support the program } \\
\text { Mayor }\end{array}$ & $\begin{array}{l}\text { - To convey the mission of the program to local agencies } \\
\text { Police Department }\end{array}$ \\
\hline - To oversee pedestrian/bicyclist enforcement at \\
- $\begin{array}{l}\text { participating schools } \\
\text { To address personal safety issues }\end{array}$ \\
\hline Crossing Guards & $\begin{array}{l}\text { - To monitor traffic flow for children walking/biking to } \\
\text { school }\end{array}$ \\
\hline
\end{tabular}

Source: Street Smart, 2014 
Table 3: Community Partners - Municipal/Government Representatives

\begin{tabular}{|c|c|}
\hline $\begin{array}{l}\text { Transportation Department } \\
\text { / Traffic Engineering }\end{array}$ & $\begin{array}{l}\text { - Oversee and provide traffic safety data/information } \\
\text { - Conduct walk audits to evaluate and implement } \\
\text { pedestrian/bicyclist safety improvements } \\
\text { - Knowledge of land use context to appropriately integrate } \\
\text { pedestrian/bicyclist improvements } \\
\text { - Responsible for preparing master plan provisions for } \\
\text { pedestrians/bicyclists } \\
\text { - Develop suggested walking and biking route maps }\end{array}$ \\
\hline $\begin{array}{c}\text { Parks, Recreation \& } \\
\text { Neighborhood Services } \\
\text { Department }\end{array}$ & $\begin{array}{l}\text { - Evaluate and oversee local parks information } \\
\text { - Provide information about how parks can be integrated } \\
\text { into walking/biking networks }\end{array}$ \\
\hline Environmental Department & $\begin{array}{l}\text { - Provide insights regarding environmental components } \\
\text { that complement the mission of the WnR program }\end{array}$ \\
\hline School Parents & $\begin{array}{l}\text { - Participate in walk audits to identify barriers that pertain } \\
\text { to walking/biking along school routes } \\
\text { - Provide information regarding factors that prevent } \\
\text { parents from allowing their child to actively travel to } \\
\text { school } \\
\text { - Educate and encourage other parents about the efforts of } \\
\text { the program }\end{array}$ \\
\hline Superintendents & $\begin{array}{l}\text { - Support the program district-wide by encouraging Safe } \\
\text { Routes to School } \\
\text { - Ensure that the mission of the WnR program aligns with } \\
\text { district policies } \\
\text { - Oversee physical infrastructure and engineering projects } \\
\text { on school sites }\end{array}$ \\
\hline $\begin{array}{l}\text { Board of Education and } \\
\text { Other District } \\
\text { Administrators }\end{array}$ & $\begin{array}{l}\text { - Establish and adopt policies that support the } \mathrm{WnR} \\
\text { program }\end{array}$ \\
\hline
\end{tabular}




\begin{tabular}{|c|ll|}
\hline & $\begin{array}{l}\text { - } \\
\text { Principals }\end{array}$ & $\begin{array}{l}\text { Integrate the culture of the WnR program into their } \\
\text { curriculum and special events } \\
\text { - }\end{array}$ \\
& $\begin{array}{l}\text { Manage engineering and physical infrastructure projects } \\
\text { on school sites }\end{array}$ \\
\hline Ensure that school policies align with the mission of the & WnR program
\end{tabular}

Source: Street Smarts, 2014 
Table 4: Community Representatives - Knowledgeable and Supportive Neighbors

\begin{tabular}{|c|c|}
\hline Local Advocates & $\begin{array}{l}\text { Provide inputs on the benefits and hindrances that } \\
\text { correspond to developing safe routes to school for } \\
\text { children }\end{array}$ \\
\hline Regional Advocates & $\begin{array}{l}\text { - Provide insights on how the WnR program can } \\
\text { successfully fit in their region } \\
\text { - Provide recommendations on pedestrian/bicycle projects } \\
\text { that can benefit their region }\end{array}$ \\
\hline Business Owners & $\begin{array}{l}\text { - Provide insights on how local businesses can coexist } \\
\text { with the program to serve communities } \\
\text { - Provide observations about pedestrian/bicycle activities } \\
\text { and sidewalk conditions that are located near their } \\
\text { boundaries } \\
\text { - Provide insights into how bicycle/pedestrian networks } \\
\text { can benefit their customers and employees }\end{array}$ \\
\hline
\end{tabular}

Source: Street Smarts, 2014 


\section{Developing School Work Plans}

WnR staff recommend committees at participating schools to develop their work plan after drafting a rough idea about the items and activities that they would like to pursue for their community (Street Smarts, 2014). It is important for schools to develop a work plan because it is an essential document that establishes a rough schedule for $\mathrm{WnR}$ related events. This document is critical because it outlines important school days and provides committees a greater sense of clarity and organization. WnR staff encourage committees to draft events and goals, located on their school work plans, by months. City staff state that this process is important because it will allow schools to effectively coordinate their events (Street Smarts, 2014). See the next few pages for a sample of a WnR participating school work plan. 
Figure 3: WnR Work Plan, Page 1

\section{Sample School Walk n' Roll Work Plan}

\begin{tabular}{|c|c|c|c|c|}
\hline No. & Month & Lead(s) & Task/Activity & Completed \\
\hline 1 & \multirow[t]{2}{*}{ Jun 2015} & $\begin{array}{l}\text { Walk n' Roll } \\
\text { Committee }\end{array}$ & Program Development: Created 12-month school workplan & v \\
\hline 2 & & $\begin{array}{l}\text { Walk n' Roll } \\
\text { Committee }\end{array}$ & $\begin{array}{l}\text { Established Walk n' Roll committee: } 6 \text { school champions and principal } \\
\text { Recruited school champions and volunteers }\end{array}$ & $\checkmark$ \\
\hline 3 & Aug 2015 & $\begin{array}{l}\text { Walk n' Roll San José } \\
\text { Staff }\end{array}$ & Conducted field observations & v \\
\hline 4 & \multirow{12}{*}{ Sep 2015} & Teachers & $\begin{array}{l}\text { Collect baseline data: conducted student tallies \& parent surveys ("Before" } \\
\text { study) ensured volunteers know how to fill this out correctly }\end{array}$ & $\checkmark$ \\
\hline 5 & & $\begin{array}{c}\text { Walk n' Roll San José } \\
\text { Staff }\end{array}$ & Provide customized parent survey forms with added text & $\checkmark$ \\
\hline 6 & & $\begin{array}{l}\text { Walk n' Roll San José } \\
\text { Staff }\end{array}$ & Receive Student Tallies & $\checkmark$ \\
\hline 7 & & $\begin{array}{l}\text { Walk n' Roll } \\
\text { Committee }\end{array}$ & Hold monthly Walk n' Roll meeting & $\checkmark$ \\
\hline 8 & & Principal & Return all student and parent surveys to Walk n' Roll San José Staff & V \\
\hline 9 & & $\begin{array}{l}\text { Walk n' Roll } \\
\text { Committee }\end{array}$ & $\begin{array}{l}\text { Plan International Walk To School Day (1st Wednesday of October) } \\
\text { Walk n' Roll San José Staff provides poster paper to school } \\
\text { Art contest for a Walk to School Day banner for the school } \\
\text { (PTA/Teachers/Students) } \\
\text { Encourage children to walk to school on October 7th (PTA/teachers) }\end{array}$ & $\checkmark$ \\
\hline 10 & & $\begin{array}{l}\text { Walk n' Roll } \\
\text { Committee }\end{array}$ & Monthly Walk n' Roll meeting & $\checkmark$ \\
\hline 11 & & $\begin{array}{l}\text { Walk n' Roll } \\
\text { Committee }\end{array}$ & Schedule Street Smarts Safety Presentation & $\checkmark$ \\
\hline 12 & & Principal & $\begin{array}{l}\text { Schedule field observation(s) (observational survey of student, pedestrian } \\
\text { behaviors \& school assessment - walkability / bikeability) }\end{array}$ & $\checkmark$ \\
\hline 13 & & $\begin{array}{c}\text { Walk n' Roll } \\
\text { Committee w/Walk } n^{\prime} \\
\text { Roll San José Staff }\end{array}$ & $\begin{array}{l}\text { Develop incentive program with milestones and sponsors: artwork, coloring } \\
\text { contests, video announcements }\end{array}$ & $\checkmark$ \\
\hline 14 & & $\begin{array}{l}\text { Walk n' Roll } \\
\text { Committee } \\
\end{array}$ & Conduct Street Smarts Safety Presentation & $\checkmark$ \\
\hline 15 & & $\begin{array}{c}\text { School } \\
\text { champion/volunteer }\end{array}$ & Receive International Walk to School Day package & $\checkmark$ \\
\hline 16 & \multirow{5}{*}{ Oct 2015} & $\begin{array}{c}\text { Walk n' Roll } \\
\text { Committee \& } \\
\text { Volunteers }\end{array}$ & International Walk to School Day on Oct 7th & $\checkmark$ \\
\hline 17 & & $\begin{array}{l}\text { Walk n' Roll } \\
\text { Committee }\end{array}$ & $\begin{array}{l}\text { Schedule special school events, publicity around school to } \\
\text { outreach/promote Walk n' Roll program, celebration events }\end{array}$ & $\checkmark$ \\
\hline 18 & & $\begin{array}{l}\text { Walk n' Roll } \\
\text { Committee }\end{array}$ & Hold monthly Walk n' Roll meeting & $\checkmark$ \\
\hline 19 & & $\begin{array}{l}\text { Walk n' Roll San José } \\
\text { Staff }\end{array}$ & Provide district-wide household map & $\checkmark$ \\
\hline 20 & & $\begin{array}{l}\text { Walk n' Roll } \\
\text { Committee }\end{array}$ & $\begin{array}{l}\text { Re-do routes and stops based on new map. Identify suitable locations for } \\
\text { students to be dropped off outside the school zone } \\
\text { (Drive part-way to school, then park and walk the rest of the way to school, } \\
\text { etc.) }\end{array}$ & $\checkmark$ \\
\hline 21 & \multirow{6}{*}{ Nov 2015} & $\begin{array}{c}\text { PTA/Walk n' Roll } \\
\text { Committee }\end{array}$ & Oversee Walking School Bus & $\checkmark$ \\
\hline 22 & & $\begin{array}{c}\text { PTA/Walk n' Roll } \\
\text { Committee }\end{array}$ & Continue Walk n' Roll outreach and promotion & $\checkmark$ \\
\hline 23 & & $\begin{array}{l}\text { PTA/Walkn' Roll } \\
\text { Committee }\end{array}$ & Continue to collect information and assess traffic and safety conditions & $\checkmark$ \\
\hline 24 & & $\begin{array}{l}\text { Walk n' Roll } \\
\text { Committee }\end{array}$ & Promote monthly Walking School Bus & v \\
\hline 25 & & $\begin{array}{l}\text { Walk n' Roll } \\
\text { Committee }\end{array}$ & Hold monthly Walk n' Roll meeting & $\checkmark$ \\
\hline 26 & & $\begin{array}{l}\text { PTA/Walk n' Roll } \\
\text { Committee }\end{array}$ & Provide parent concerns for Walk Audit & $\checkmark$ \\
\hline 27 & \multirow{2}{*}{ Dec 2015} & $\begin{array}{c}\text { PTA/Walk n' Roll } \\
\text { Committee }\end{array}$ & Continue Walk n' Roll outreach and promotion. & $\checkmark$ \\
\hline 28 & & $\begin{array}{c}\text { PTA/Walkn' Roll } \\
\text { Committee }\end{array}$ & Oversee Walking School Bus & $\checkmark$ \\
\hline 29 & \multirow{3}{*}{ Jan 2016} & $\begin{array}{c}\text { PTA/Walk n' Roll } \\
\text { Committee }\end{array}$ & Oversee Walking School Bus & $\checkmark$ \\
\hline 30 & & $\begin{array}{l}\text { PTA/Walkn' Roll } \\
\text { Committee }\end{array}$ & Conduct Walk Audit & $\checkmark$ \\
\hline 31 & & $\begin{array}{l}\text { Walk n' Roll } \\
\text { Committee }\end{array}$ & Hold monthly Walk n' Roll meeting & $\checkmark$ \\
\hline \multirow[b]{2}{*}{3} & & $\begin{array}{c}\text { PTA/Walk n' Roll } \\
\text { Committee }\end{array}$ & Oversee Walking School Bus & $\checkmark$ \\
\hline & & $\begin{array}{l}\text { Walk n' Roll } \\
\text { Committee }\end{array}$ & Hold monthly Walkn' Roll meeting & $\checkmark$ \\
\hline
\end{tabular}

Source: Street Smarts, 2014 


\section{Figure 3: WnR Work Plan, Page 2}

\section{Sample School Walk n' Roll Work Plan}

\begin{tabular}{|c|c|c|c|c|}
\hline No. & Month & Lead(s) & Task/Activity & Completed \\
\hline 34 & \multirow{5}{*}{ Feb 2016} & $\begin{array}{l}\text { Walk n' Roll } \\
\text { Committee }\end{array}$ & Submit copy of updated route map and times & $\checkmark$ \\
\hline 35 & & $\begin{array}{l}\text { Walkn' Roll } \\
\text { Committee }\end{array}$ & Submit copy of updated work plan & $v$ \\
\hline 36 & & $\begin{array}{l}\text { Walk n' Roll } \\
\text { Committee }\end{array}$ & Submit Walkn' Roll Support letter & $\checkmark$ \\
\hline 37 & & $\begin{array}{l}\text { Walkn' Roll } \\
\text { Committee }\end{array}$ & Submit PTCO letter & $\checkmark$ \\
\hline 38 & & $\begin{array}{c}\text { PTA/Walk n' Roll } \\
\text { Committee }\end{array}$ & Finish T-Shirt Design & $\checkmark$ \\
\hline 39 & \multirow{3}{*}{ Mar 2016} & $\begin{array}{l}\text { PTA/Walkn' Roll } \\
\text { Committee }\end{array}$ & Oversee Walking School Bus/Conduct Crossing Counts & $\checkmark$ \\
\hline 40 & & $\begin{array}{l}\text { Walk n' Roll } \\
\text { Committee }\end{array}$ & Hold monthly Walk n' Roll meeting & $\mathrm{v}$ \\
\hline 41 & & $\begin{array}{c}\text { Street Smarts } \\
\text { Representative }\end{array}$ & Bike Rodeo & $\checkmark$ \\
\hline 42 & \multirow{5}{*}{ Apr 2016} & $\begin{array}{c}\text { PTA/Walk n' Roll } \\
\text { Committee }\end{array}$ & Oversee Walking School Bus/Conduct Crossing Counts & $\mathrm{v}$ \\
\hline 43 & & $\begin{array}{l}\text { Walkn' Roll } \\
\text { Committee }\end{array}$ & Hold monthly Walk n' Roll meeting & $\mathrm{v}$ \\
\hline 44 & & $\begin{array}{c}\text { Walk n' Roll San José } \\
\text { Staff }\end{array}$ & Provide update on incentive specifics & $\checkmark$ \\
\hline 45 & & $\begin{array}{l}\text { PTA/Walk n' Roll } \\
\text { Committee }\end{array}$ & Get T-Shirt Design Printed & \\
\hline 46 & & $\begin{array}{c}\text { PTA/Walk n' Roll } \\
\text { Committee }\end{array}$ & Get T-Shirt Design Distributed Walking School Bus in time for May & \\
\hline 47 & \multirow{4}{*}{ May 2016} & $\begin{array}{l}\text { PTA/Walk n' Roll } \\
\text { Committee }\end{array}$ & Oversee BIKE TO SCHOOL DAY - MaY 4th & \\
\hline 48 & & $\begin{array}{c}\text { PTA/Walk n' Roll } \\
\text { Committee }\end{array}$ & Oversee Walking School Bus/Conduct Crossing Counts & \\
\hline 49 & & $\begin{array}{l}\text { Walk n' Roll } \\
\text { Committee }\end{array}$ & Hold monthly Walk n' Roll meeting & \\
\hline 50 & & $\begin{array}{c}\text { PTA/Walkn' Roll } \\
\text { Committee }\end{array}$ & Oversee Walking School Bus/Conduct Crossing Counts & \\
\hline 51 & \multirow{2}{*}{ Jun 2016} & $\begin{array}{l}\text { PTA/Walkn' Roll } \\
\text { Committee }\end{array}$ & Oversee Walking School Bus & \\
\hline 52 & & $\begin{array}{l}\text { Walk n' Roll } \\
\text { Committee }\end{array}$ & Hold monthly Walk n' Roll meeting & \\
\hline
\end{tabular}

Source: Street Smarts, 2014 


\section{November}

WnR staff use this month to establish suggested walking routes and organize monthly and weekly walk/bike to school day events. Schools coordinate walk/bike to school day events to create opportunities for children and their parents to interact and socialize with their peers. One of the main responsibilities for $\mathrm{WnR}$ staff during this month is to help schools in identifying safe, accessible and direct routes to school for children to travel (Street Smarts, 2014).

\section{Walk and Bike to School Day Events}

WnR staff encourage schools to organize walk/bike to school day events on a weekly basis because they can benefit communities in many facets. City staff argue that these events provide opportunities to teach pedestrian/bicycle safety skills to children. Many parents state that weekly/monthly walking and biking to school day events are effective because they create a positive experience for children that encourages them to travel independently to school later in life (Street Smarts, 2014).

\section{Safe Routes to School Map}

WnR staff are responsible for developing route maps for participating schools. School maps are beneficial to children and their parents because they illustrate convenient and accessible walking/biking routes to and from school. These maps help schools identify areas that they should have their students avoid when they are walking/biking to school; intersections with high traffic volumes, routes with lack of walkways, and places with the absence of controlled street crossings (Street Smarts, 2014).

The city focuses on identifying the location of where students live in their school boundary area to identify suggested walking and biking routes. WnR staff concentrate on obtaining observations/concerns from children and parents who reside in school boundaries and 
are already walking and biking to school or are interested in active transportation. City staff argue that the preliminary steps of developing school maps help staff members in recruiting parent volunteers for WnR committees. School maps are an effective tool because they help schools develop walking school buses and bike trains (Street Smarts, 2014). See the next page for an example of a $\mathrm{WnR}$ participating school map. 
Figure 4: WnR Participating School Map

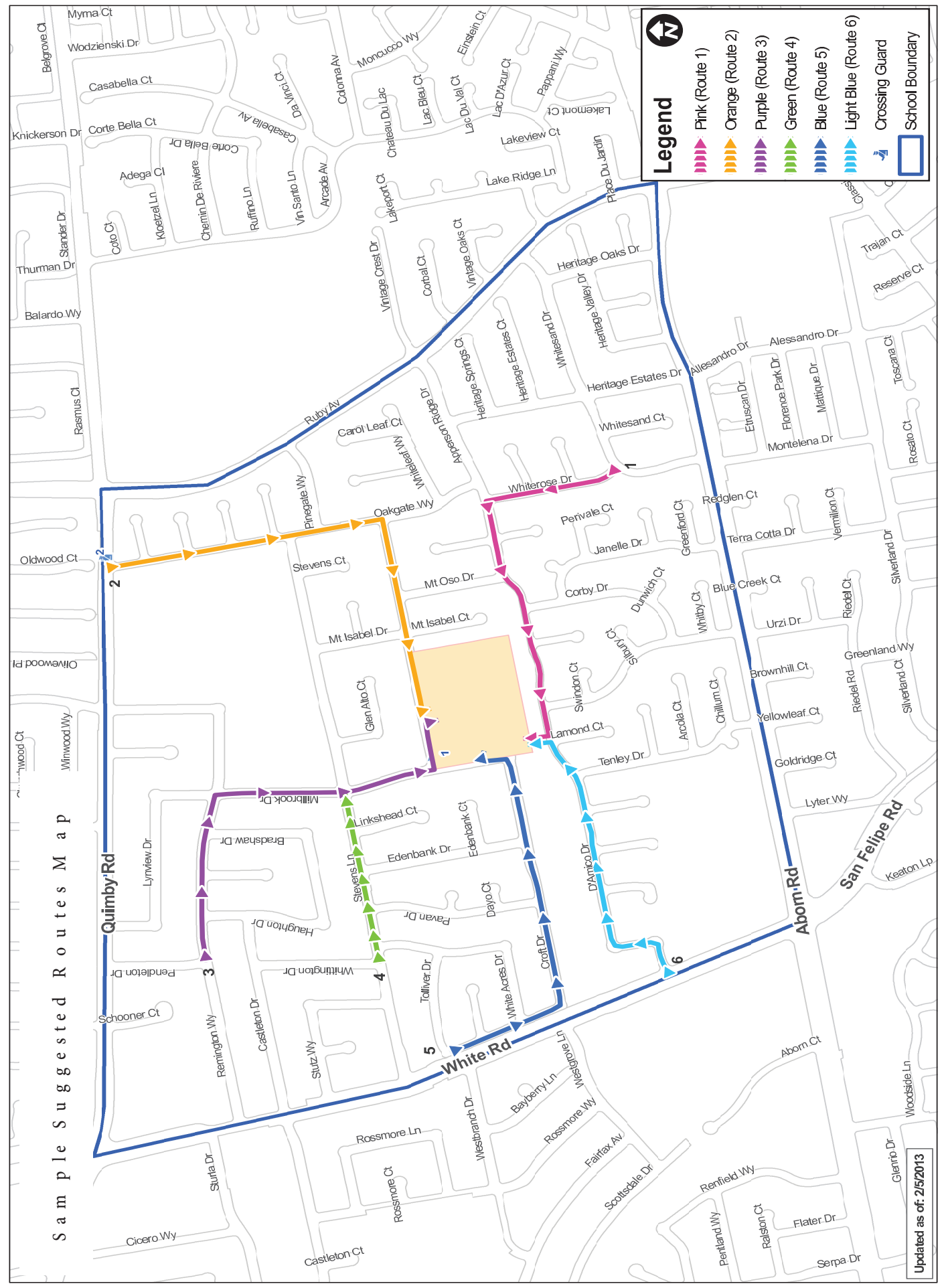

Source: Street Smarts, 2014 


\section{December}

The WnR program sponsors two main events throughout this month: walking school buses and bike trains (Street Smarts, 2014). The purpose of organizing these events is to help schools alleviate the level of fear for parents when they are allowing their children to walk/bike to school. According to many schools, safety is one of the main reasons to why parents do not support their children in actively commuting to school (Street Smarts, 2014).

\section{Walking School Buses and Bike Trains}

WnR staff are responsible for helping schools in establishing walking school buses and bike trains. Schools can choose to operate these events daily, weekly, or monthly (Street Smarts, 2014). The routes of walking school buses and bike trains are usually originated in particular neighborhoods. Both options can be loosely structured or highly organized. Many schools simply connect neighborhood families who enjoy walking and biking together. Schools can choose to be formal when organizing walking school buses and bike trains by having a coordinator who recruits volunteers and participants, creates schedules, and designs walking routes (Street Smarts, 2014).

The program urges schools to participate in developing a neighborhood school pool network when they have established a walking school bus and/or a bike train (Street Smarts, 2014). The school pool network allows parents to share the duties of getting children to and from school. The network pool includes carpooling, walking school buses, bike trains, or arranging bus buddies for school buses or public transit. Typically, two or more families agree to share responsibilities by trading days as pool leaders. This feature of the program is beneficial for parents because it allows them to save time and provide their children a safer way to travel to and from school (Street Smarts, 2014). 


\section{January}

The WnR program assists schools in conducting walk audits and solving route infrastructure issues that hinder children from walking and biking to school during this month. WnR staff members focus on gathering observations and concerns from parents and community members about route issues within school sites. The program operates under San Jose's Department of Transportation. The department is responsible for operating, maintaining, and improving crosswalks, signs, bike lanes, sidewalks, and pavement markings in San Jose. Walk audits are beneficial for participating schools because they help communities enhance their walking and biking route infrastructure (Street Smarts, 2014). See the next page for a sample of a walk audit form. 
Figure 5: WnR Walk Audit Form

\section{"Your School" - Walk 'n Roll Walk Audit Undertaken January 2015}

\begin{tabular}{|c|c|c|c|c|}
\hline $\begin{array}{l}\text { Item } \\
\text { No. }\end{array}$ & Route & Location & Issues & $\begin{array}{l}\text { Suggested Physical } \\
\text { Enhancement }\end{array}$ \\
\hline 1 & 1 & $\begin{array}{l}\text { Two corners at Parkwood } \\
\text { Wy. and Brentmoor Dr. }\end{array}$ & $\begin{array}{l}\text { No ADA sidewalk ramps on the } \\
\text { corners }\end{array}$ & $\begin{array}{l}\text { All corners to have ADA compliant } \\
\text { sidewalk ramps. }\end{array}$ \\
\hline 2 & 1 & Cara Ave. & $\begin{array}{l}\text { Speeding concerns at high volumes. } \\
\text { No signs indicating drivers to slow } \\
\text { down. }\end{array}$ & $\begin{array}{l}\text { Install "Slow Down Pedestrian } \\
\text { Crossing" signs. }\end{array}$ \\
\hline 3 & 1 & $\begin{array}{l}\text { On Ashville Wy. (in } \\
\text { between Elmwell Dr. \& } \\
\text { Northdale Dr.) }\end{array}$ & $\begin{array}{l}\text { Missing sidewalk (on right side of } \\
\text { street heading towards Northdale Dr.) }\end{array}$ & Install new sidewalk on Ashville Wy. \\
\hline 4 & 1 & $\begin{array}{l}\text { On Ayelene Dr. (in } \\
\text { between Brent Wy. And } \\
\text { Rento St.) }\end{array}$ & $\begin{array}{l}\text { Raised sidewalks (both sides of } \\
\text { street), which may cause danger to } \\
\text { pedestrians. }\end{array}$ & $\begin{array}{l}\text { Request to smooth/level out } \\
\text { sidewalks. }\end{array}$ \\
\hline 5 & 1 & $\begin{array}{l}\text { Corner of Rento St. \& } \\
\text { May Dr. }\end{array}$ & Stop sign blocked by tree. & Request to trim tree. \\
\hline 6 & 1 & $\begin{array}{l}\text { Cherrywine Dr. \& Meryl } \\
\text { Ave. }\end{array}$ & $\begin{array}{l}\text { No crosswalk, high pedestrian } \\
\text { activity. }\end{array}$ & $\begin{array}{l}\text { Install raised crosswalk/White } \\
\text { Zebra crossing. }\end{array}$ \\
\hline 7 & 1 & Venicia Wy. \& Meryl Ave. & $\begin{array}{l}\text { Vehicles park too close to } \\
\text { intersection/returns, creating visibility } \\
\text { issues. }\end{array}$ & $\begin{array}{l}\text { Refresh red paint near all } \\
\text { intersection/return and possible } \\
\text { extension of red curb painting. }\end{array}$ \\
\hline 8 & 1 & $\begin{array}{l}\text { On Rinabor Dr. (in } \\
\text { between Northdale Dr. \& } \\
\text { Meryl St. }\end{array}$ & Mid-Block crossing, illegal U-turns & Traffic Enforcement. \\
\hline 9 & 2 & $\begin{array}{l}\text { All four } \\
\text { corners/intersections at } \\
\text { Elm Ave. Strawpine Dr. }\end{array}$ & $\begin{array}{l}\text { Pedestrian safety concerns; Seven } \\
\text { accidents reported at this location } \\
\text { alone. }\end{array}$ & Request for a 4-way Stop sign. \\
\hline 10 & 2 & $\begin{array}{l}\text { Corner of Elm Ave. \& } \\
\text { Cherrydale Dr. }\end{array}$ & $\begin{array}{l}\text { High hedges provide visibility } \\
\text { concerns for pedestrians at this } \\
\text { corner (near 1-way stop sign) }\end{array}$ & $\begin{array}{l}\text { Cut hedges to provide better } \\
\text { visibility. }\end{array}$ \\
\hline
\end{tabular}

Source: Street Smarts, 2014 


\section{February - June}

Throughout this time frame of the year, schools focus on many objectives, such as developing safety patrols, expanding $\mathrm{WnR}$ committees, assessing the progress of the program, and organizing bike rodeos and bike to school days. WnR staff members collaborate with the Safety and Education Unit from San Jose's Police Department to help schools certify their safety patrol division. Students in $5^{\text {th }}$ and $6^{\text {th }}$ grade qualify to oversee their school's safety patrol division, and San Jose's Police Department is responsible for training participants (Street Smarts, 2014).

WnR staff members assist schools in expanding their WnR committee throughout March, to help schools recruit and train new members. This process is essential because it allows schools to effectively sustain a productive committee for the following school year. In April, schools are required to conduct the end of the year student tallies and administer parent surveys. Throughout May and June, WnR staff members collaborate with Street Smarts to help schools organize bike rodeos, bike helmet fittings, and/or bike safety workshops for Bike to School Day (Street Smarts, 2014). 


\section{WnR Participating Schools}

The WnR program assisted more than 60 schools in San Jose with promoting active transportation in 2018. The program provided resources and services to participating schools to help students in actively commuting to and from school safely. Participating WnR schools also received help in easing traffic congestion and alleviating the frequency of reckless driving from parents near school zones (Street Smarts, 2018). The program currently serves 12 school districts: Alum Rock Union School District, Berryessa Union School District, Cambrian School District, Campbell Union School District, Cupertino Union School District, Evergreen School District, Luther Burbank School District, Moreland School District, Mount Pleasant School District, Oak Grove School District, San Jose Unified School District, and Union School District (Street Smarts, 2018). Of the 12 participating school districts, Berryessa Union School District, Evergreen School District, and Mount Pleasant School District are “Walk n' Roll School District Wide Participants.” All three school districts require every elementary and middle school located in their jurisdiction to enroll in the WnR program and instill the program's culture into their curriculum (Street Smarts, 2018). 


\section{Schools with the Highest WnR Success Rate}

Table 5: Schools with Highest Active Transportation Percentage

\begin{tabular}{|l|c|c|c|}
\hline \multicolumn{1}{|c|}{ School Name } & School District & Baseline Year & Fall 2018 \\
\hline School A $\left(1^{\text {st }}\right)$ & Evergreen & Fall 2017 & $46.3 \%$ \\
\hline School B $\left(2^{\text {nd }}\right)$ & Evergreen & Fall 2015 & $46.2 \%$ \\
\hline School C $\left(3^{\text {rd }}\right)$ & Evergreen & Fall 2016 & $42.1 \%$ \\
\hline School D $\left(4^{\text {th }}\right)$ & Berryessa Union & Fall 2016 & $41.5 \%$ \\
\hline School E $\left(5^{\text {th }}\right)$ & Evergreen & Spring 2012 & $41.2 \%$ \\
\hline School F $\left(6^{\text {th }}\right)$ & Alum Rock Union & Spring 2014 & $40.0 \%$ \\
\hline School G $\left(7^{\text {th }}\right)$ & Cambrian & Spring 2017 & $39.0 \%$ \\
\hline School H $\left(8^{\text {th }}\right)$ & Union & Fall 2016 & $37.0 \%$ \\
\hline School I $\left(9^{\text {th }}\right)$ & Mount Pleasant & Fall 2015 & $36.4 \%$ \\
\hline School J $\left(10^{\text {th }}\right)$ & Union & Fall 2016 & $36.0 \%$ \\
\hline
\end{tabular}

Source: City of San Jose's Walk n’ Roll Program, 2018

\section{Table 5 Analysis}

Table 5 shows that the top 10 schools with the highest active transportation percentage were from Evergreen School District, Berryessa Union School District, Alum Rock Union School District, Cambrian School District, Union School District, and Mount Pleasant School District during the Fall of 2018. The top 3 schools (School A, B, and C) and School E ( $5^{\text {th }}$ place) were from Evergreen School District. The top 3 schools had at least $42 \%$ of their students walking, biking, or using other active means, such as scooters and skateboards, to travel to and from school. School E had $41 \%$ of their total school population who were actively commuting to and from school.

Berryessa Union School District was represented in $4^{\text {th }}$ place by School D. School D had a $42 \%$ percentage. Alum Rock Union School District fell in $6^{\text {th }}$ place with School F achieving a 40\% percentage. Surprisingly, Cambrian School District and Union School District were represented by School G ( $7^{\text {th }}$ place $), H$ ( $8^{\text {th }}$ place $)$, and J $\left(10^{\text {th }}\right.$ place $)$ even though they were not 
part of the districts that required their schools to integrate WnR into their culture. Mount Pleasant School District came in $9^{\text {th }}$ place with a $36 \%$ percentage from School I. 
Table 6: Schools with Highest Mode Shift Percentage

\begin{tabular}{|l|c|c|c|}
\hline School Name & School District & Baseline Year & Fall 2018 \\
\hline School A $\left(1^{\text {st }}\right)$ & Cambrian & Spring 2017 & $84.4 \%$ \\
\hline School B $\left(2^{\text {nd }}\right)$ & Berryessa Union & Spring 2016 & $79.4 \%$ \\
\hline School C $\left(3^{\text {rd }}\right)$ & Evergreen & Fall 2017 & $65.1 \%$ \\
\hline School D $\left(4^{\text {th }}\right)$ & Evergreen & Spring 2012 & $61.6 \%$ \\
\hline School E $\left(5^{\text {th }}\right)$ & Evergreen & Spring 2014 & $60.6 \%$ \\
\hline School F $\left(6^{\text {th }}\right)$ & Evergreen & Fall 2015 & $56.4 \%$ \\
\hline School G $\left(7^{\text {th }}\right)$ & Berryessa Union & Fall 2016 & $56.0 \%$ \\
\hline School H $\left(8^{\text {th }}\right)$ & Evergreen & Fall 2016 & $50.5 \%$ \\
\hline School I $\left(9^{\text {th }}\right)$ & Moreland & Spring 2012 & $48.1 \%$ \\
\hline School J $\left(10^{\text {th }}\right)$ & Evergreen & Fall 2012 & $47.4 \%$ \\
\hline
\end{tabular}

Source: City of San Jose's Walk n' Roll Program, 2018

\section{Table 6 Analysis}

Table 6 demonstrates that Cambrian School District, Berryessa Union School District, Evergreen School District, and Moreland School District were the jurisdictions that had the most success in sustaining a high mode shift percentage in active transportation among students during the Fall of 2018. Cambrian School District was represented by School A ( $\left(1^{\text {st }}\right.$ place) with $84 \%$ of its participating students changing from passive to active transportation. School B ( $2^{\text {nd }}$ place $)$ and School G ( $7^{\text {th }}$ place) represented Berryessa Union School District with a 79\% and 56\% percentage. Moreland School District fell in $9^{\text {th }}$ place with a $48 \%$ percentage from School I. Evergreen School District had the most schools on the list (6), with at least a 47\% mode shift percentage or above from each institution (School C, D, E, F, H, and J). The placement of School A was the most surprising finding from this analysis; Cambrian School District is not a WnR School District Wide participant. 
Table 7: Schools Under Both Standards (High Active Transportation/High Mode Shift \%)

\begin{tabular}{|c|c|c|c|c|}
\hline $\begin{array}{c}\text { School } \\
\text { Name }\end{array}$ & School District & $\begin{array}{c}\text { Baseline } \\
\text { Year }\end{array}$ & $\begin{array}{c}\text { Name Under } \\
\text { Table 5 }\end{array}$ & $\begin{array}{c}\text { Name Under } \\
\text { Table 6 }\end{array}$ \\
\hline School GA & Cambrian & Spring 2017 & School G & School A \\
\hline School ED & Evergreen & Spring 2012 & School E & School D \\
\hline School DG & Berryessa Union & Fall 2016 & School D & School G \\
\hline School CH & Evergreen & Fall 2016 & School C & School H \\
\hline
\end{tabular}

From table 6, Schools A, D, G, and H were also on the list that illustrated the top 10 schools that had the highest active transportation percentage during the Fall of 2018 (table 5). Table 7 combines the letters of all four schools from their name on table 5 and 6 to create a new name for their classification for the category of "Schools Under Both Standards (High Active Transportation/High Mode Shift \%).” All four schools started with a baseline percentage that was below their current student tally data measure: School GA's baseline, Spring 2017 (21.1\%), Fall 2018 percentage (39\%); School ED’s baseline, Spring 2012 (25.5\%), Fall 2018 percentage (41.2\%); School DG's baseline, Fall 2016 (26.6\%), Fall 2018 percentage (41.5\%); School CH's baseline, Fall 2016 (21.4\%), Fall 2018 percentage (42.1\%). (City of San Jose's Walk n’ Roll Program, 2018).

Throughout their enrollment time frame in the program, all four schools have always achieved a $20 \%$ mode shift percentage or higher after the measurement of their baseline. School GA's mode shift percentages were Fall 2017 (84.8\%), Spring 2018 (117.1\%), and Fall 2018 (84.4\%). School ED’s mode shift percentages were Fall 2012 (22.4\%), Spring 2013 (35.3\%), Fall 2013 (65.9\%), Spring 2014 (85.5\%), Fall 2014 (65.1\%), Spring 2015 (55.6\%), Fall 2015 (44.7\%), Spring 2016 (45.1\%), Fall 2016 (49.8\%), Spring 2017 (36.1\%), Fall 2017 (33.3\%), Spring 2018 (40\%), and Fall 2018 (61.6\%). School DG's mode shift percentages were Spring 2017 (75.6\%), Fall 2017 (99.2\%), Spring 2018 (66.9\%), and Fall 2018 (56\%). School CH’s 
mode shift percentages were Spring 2017 (86.9\%), Fall 2017 (72.9\%), school did not conduct the tallies in Spring 2018, and Fall 2018 (50.5\%). (City of San Jose's Walk n' Roll Program, 2018). (See figures 7, 9, 11, and 13 for a mode shift graphic analytic of all four schools; Schools GA, ED, DG, and $\mathrm{CH})$. 
Data/Analysis for High Active Transportation and High Mode Shift \% Schools

\section{School GA}

Table 8: School GA Student Tally Measures Data

\begin{tabular}{|l|c|c|c|c|c|}
\hline \multicolumn{1}{|c|}{ Season } & Population & Walk \% & Bike \% & $\begin{array}{c}\text { Other \% } \\
\text { (Skateboard/Scooter) }\end{array}$ & $\begin{array}{c}\text { Total \% } \\
\text { (Active Transportation) }\end{array}$ \\
\hline Spring 2017 & 950 & $19.0 \%$ & $2.0 \%$ & $0.1 \%$ & $21.1 \%$ \\
\hline Fall 2017 & 1030 & $31.0 \%$ & $7.0 \%$ & $0.5 \%$ & $38.5 \%$ \\
\hline Spring 2018 & 1006 & $41.0 \%$ & $4.0 \%$ & $0.8 \%$ & $45.8 \%$ \\
\hline Fall 2018 & 963 & $29.0 \%$ & $9.0 \%$ & $0.9 \%$ & $38.9 \%$ \\
\hline
\end{tabular}

Figure 6: School GA Student Tally Measures

\section{School GA}

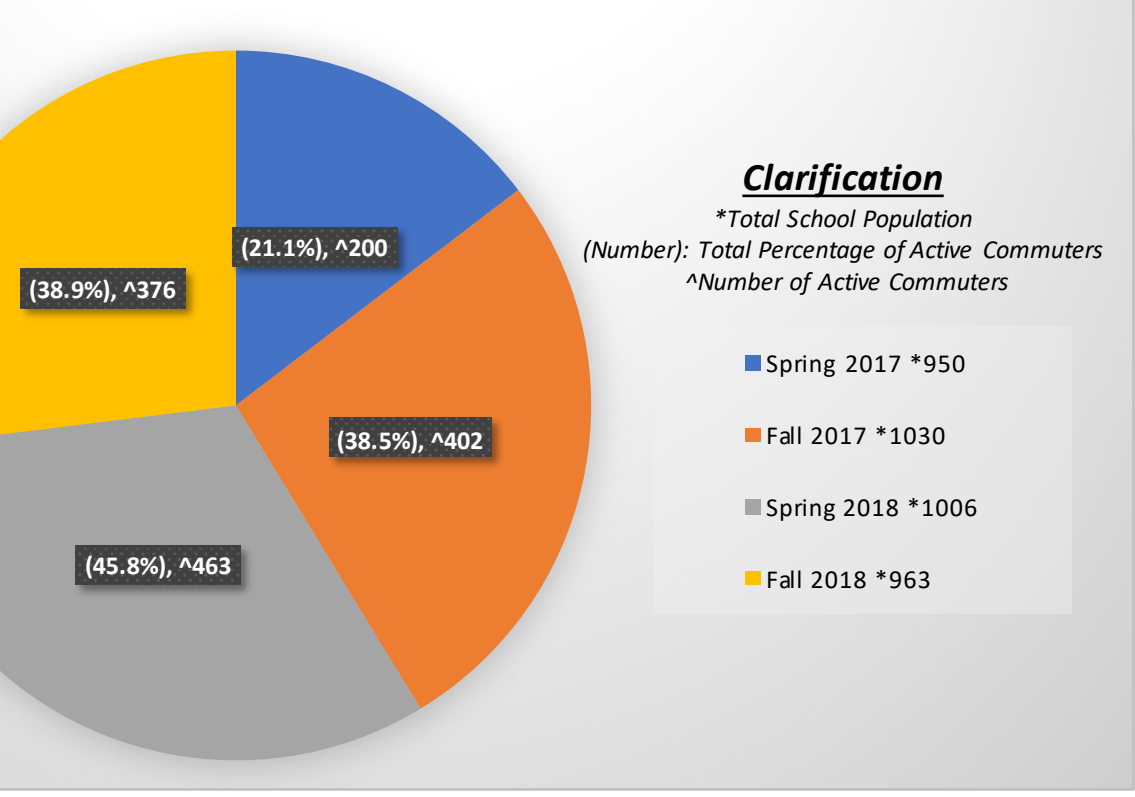

Source: City of San Jose's Walk n' Roll Program, 2018 


\section{School GA Graphic Analysis}

Figure 6 demonstrates that School GA joined the WnR program in Spring 2017. The school had a total number of 200 students from its 950 children population who were actively commuting to and from school. After their first season in being enrolled in the program, School GA's total active commuters was augmented by more than 200 students for the following season (Fall 2017), for a total of 402 active commuters. One of the primary factors that led to this increase in the number of students who were walking, biking, or using other active alternatives to travel to school was a peak in enrollment for School GA.

The school's total population increased by an additional 80 students $(1030-950)$ from their starting baseline population of 950 children during the following season, Fall 2017. After being enrolled in the program for one-year (Spring 2018), the total number for active commuters for School GA was augmented by an additional 263 students ( $463-200)$, and the school had an increase of $25 \%(46 \%-21 \%)$ in their percentage of students who were actively commuting to and from school from their baseline measure. For the Fall of 2018, the school had a decrease in their student population, and it negatively impacted the total number of their active commuters. 


\section{School GA Strategies for Achieving and Sustaining Success}

School GA is able to achieve and maintain success in the program by engaging their student population to walk to school at least once per month. The school focuses on organizing events such as Monthly Walk to School Days and International Walk to School Day to promote active transportation and traffic safety. Both events help children in carrying the momentum of active transportation throughout the school year because students are able to connect with their community and experience the positive impacts of walking and biking to school. In addition, the school provides brochures and incentive items that pertain to active transportation throughout their yearly school events to encourage students to walk and bike to school (City of San Jose's Walk n' Roll Program, 2018).

One of the main factors that contributes to the success of School GA in the WnR program is its proximity to an elementary WnR participating school. School GA is a middle school that is located within a 200-meter length from an elementary school that actively supports their students in walking and biking to school. The elementary school that is nearby School GA has numerous established walking school buses, which usually have more than five students, with the supervision of an adult, walking and/or biking to school. School GA is able to achieve and sustain success with limited active transportation events (Monthly Walk to School Days and International Walk to School Day), as oppose to coordinating Weekly Walk to School Days, Bike Rodeos, Safety Assemblies, and Walkathons, because most of their students usually transition from the nearby elementary school with the culture of WnR already instilled into their daily lives (City of San Jose's Walk n' Roll Program, 2018). 
*Baseline

N/A: Not Applicable

Reminders

- The city requires a 20\% mode shift percentage or above after baseline measurement

- $\quad$ Mode Shift $=$ Current Period Percentage - Baseline Percentage $/$ Baseline Percentage

Table 9: School GA Mode Shift Data

\begin{tabular}{|l|c|c|}
\hline \multicolumn{1}{|c|}{ Season } & $\begin{array}{c}\text { Current Period \% } \\
\text { Active Transportation) }\end{array}$ & Mode Shift \% \\
\hline *Spring 2017 & $21.1 \%$ & N/A \\
\hline Fall 2017 & $38.5 \%$ & $82.0 \%$ \\
\hline Spring 2018 & $45.8 \%$ & $117.0 \%$ \\
\hline Fall 2018 & $38.9 \%$ & $84.0 \%$ \\
\hline
\end{tabular}

Figure 7: School GA Mode Shift

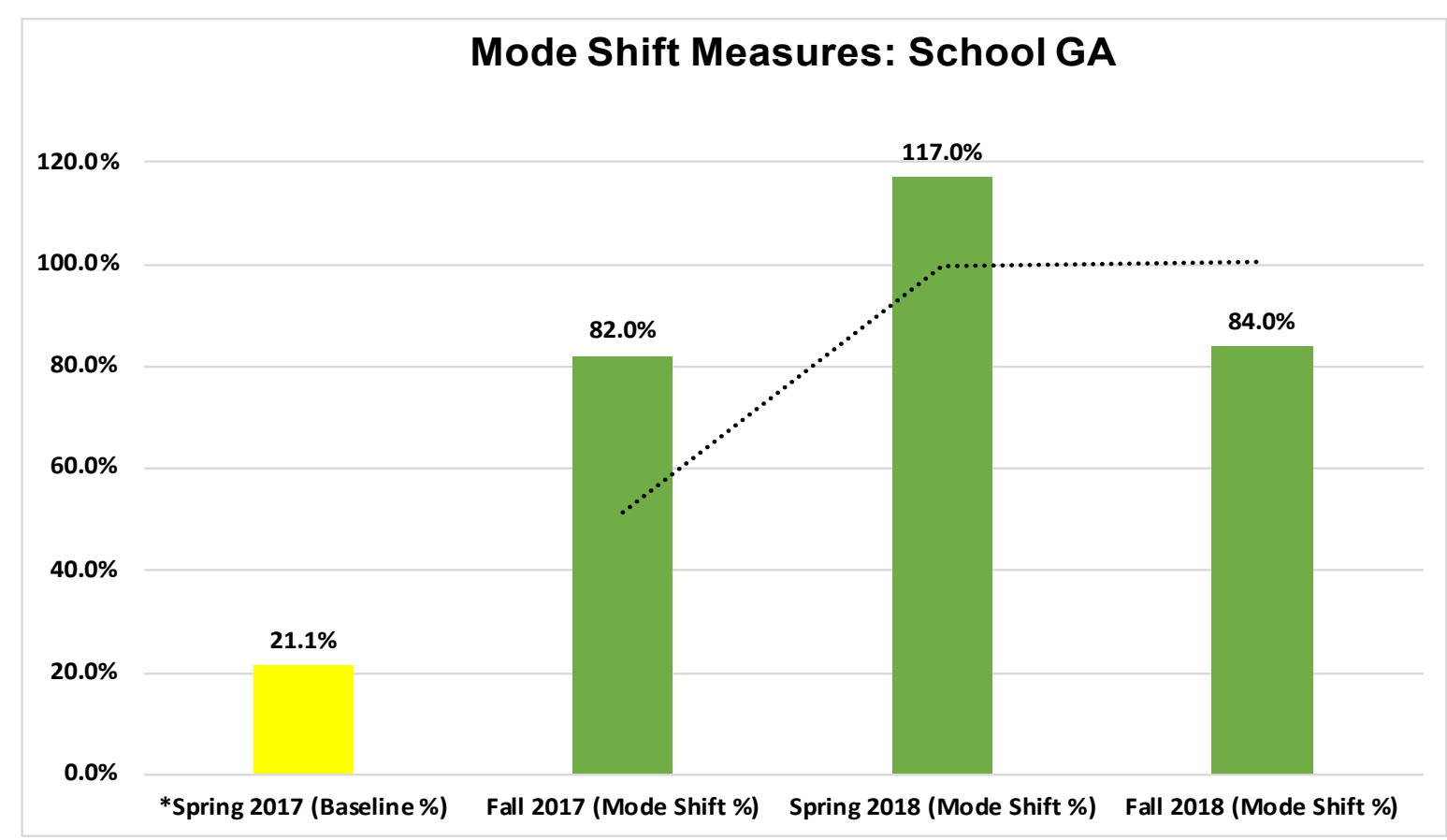

Source: City of San Jose's Walk n’ Roll Program, 2018 


\section{School ED}

Table 10: School ED Student Tally Measures Data

\begin{tabular}{|l|c|c|c|c|c|}
\hline \multicolumn{1}{|c|}{ Season } & Population & Walk \% & Bike \% & $\begin{array}{c}\text { Other \% } \\
\text { (Skateboard/Scooter) }\end{array}$ & $\begin{array}{c}\text { Total \% } \\
\text { (Active Transportation) }\end{array}$ \\
\hline Spring 2012 & 700 & $24.0 \%$ & $0.5 \%$ & $1.0 \%$ & $25.5 \%$ \\
\hline Fall 2012 & 766 & $30.0 \%$ & $1.0 \%$ & $0.2 \%$ & $31.2 \%$ \\
\hline Spring 2013 & 776 & $34.0 \%$ & $0.4 \%$ & $0.1 \%$ & $34.5 \%$ \\
\hline Fall 2013 & 751 & $41.0 \%$ & $1.0 \%$ & $0.3 \%$ & $42.3 \%$ \\
\hline Spring 2014 & 749 & $46.0 \%$ & $1.0 \%$ & $0.3 \%$ & $47.3 \%$ \\
\hline Fall 2014 & 728 & $41.0 \%$ & $0.9 \%$ & $0.2 \%$ & $42.1 \%$ \\
\hline Spring 2015 & 743 & $39.0 \%$ & $0.6 \%$ & $0.1 \%$ & $39.7 \%$ \\
\hline Fall 2015 & 715 & $35.0 \%$ & $1.0 \%$ & $0.9 \%$ & $36.9 \%$ \\
\hline Spring 2016 & 721 & $36.0 \%$ & $0.5 \%$ & $0.5 \%$ & $37.0 \%$ \\
\hline Fall 2016 & 649 & $37.0 \%$ & $1.0 \%$ & $0.2 \%$ & $38.2 \%$ \\
\hline Spring 2017 & 644 & $34.0 \%$ & $0.6 \%$ & $0.1 \%$ & $34.7 \%$ \\
\hline Fall 2017 & 667 & $33.0 \%$ & $0.2 \%$ & $0.5 \%$ & $33.7 \%$ \\
\hline Spring 2018 & 681 & $35.0 \%$ & $0.6 \%$ & $0.2 \%$ & $35.8 \%$ \\
\hline Fall 2018 & 618 & $40.0 \%$ & $1.0 \%$ & $0.2 \%$ & $41.2 \%$ \\
\hline
\end{tabular}


Figure 8: School ED Student Tally Measures

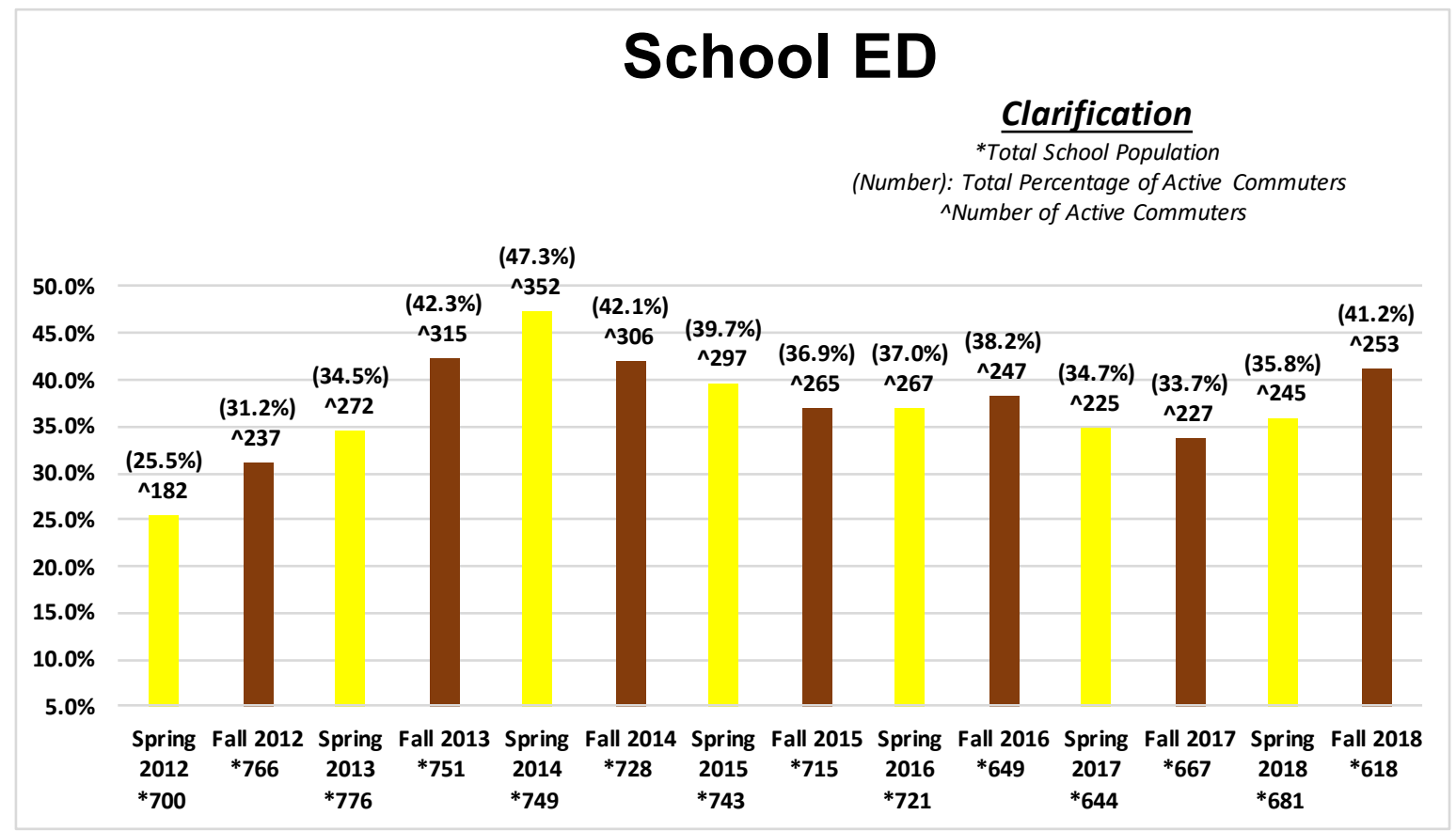

Source: City of San Jose's Walk n’ Roll Program, 2018 


\section{School ED Graphic Analysis}

Based on figure 8, School ED has been able to increase the number of their students who actively commute to and from school throughout their time frame enrolled in the program. The school started with a baseline of 182 students who were actively traveling to and from school. One of the school's best highlights, was the increase in the number of its students who were actively commuting to school from Fall 2012 through Spring 2014, 170 additional children $(55+35+43$ $+37)$.

[After the Fall of 2018, School ED was able to increase and retain 71 active commuters $(55+35+43+37-46-9-32+2-20-22+2+18+8)$. Fall 2012 added 55 from 182; Spring 2013 added 35 from 237; Fall 2013 added 43 from 272; Spring 2014 added 37 from 315; Fall 2014 lost 46 from 352; Spring 2015 lost 9 from 306; Fall 2015 lost 32 from 297; Spring 2016 added 2 from 265; Fall 2016 lost 20 from 267; Spring 2017 lost 22 from 247; Fall 2017 added 2 from 225; Spring 2018 added 18 from 227; and Fall 2018 added 8 from 245.]

[The school suffered a decrease of $87(46+9+32)$ in students who were walking, biking, or using other active means from Fall 2014 through Fall 2015. In Spring 2016, the school added 2 additional active commuters from their previous season's measurement. From Fall 2016 through Spring 2017, School ED experienced another decrease of $22(225-247)$ in active commuters. The school is now starting to get back on track with an augmentation of 26 (253227) students who actively traveled to school from Fall 2017 through Fall 2018.] 


\section{School ED Strategies for Achieving and Sustaining Success}

School ED is one of the most successful schools in the WnR program because they have an established and reliable WnR committee. The school champions the program by hosting Weekly Walk to School Days, International Walk to School Day, Bike Rodeos, Safety Assemblies, and other events that relate to active transportation and traffic safety. The school is one of the few participating WnR schools that starts coordinating their Weekly Walk to School Day events in the first week of school. This strategy is beneficial because it helps the institution start and build a strong momentum for active transportation for International Walk to School Day and the remainder of the school year (City of San Jose's Walk n' Roll Program, 2018).

School ED is consistent in hosting bike rodeo events since they have joined the program. The school participates annually, and they usually have over 100 children who receive cycling safety tips and learn new biking skills (City of San Jose's Walk n' Roll Program, 2018). The school organizes safety assemblies once per two years. Assemblies teach students strategies and techniques that they can incorporate into their daily comportment to appropriately conduct themselves when they are actively traveling to school. WnR staff supports School ED in promoting active transportation safety through school events with designed structures such as safety pamphlet guidelines and a spinning wheel device that includes active transportation and traffic safety graphics with relatable questions. Safety pamphlet guidelines are allocated to parents and students throughout the events that staff attend, to help raise awareness for active transportation and traffic safety. Students are able to play and interact with WnR staff by spinning the wheel (Similar to Wheel of Fortune) and receiving a question based on the active transportation or traffic safety illustration where the wheel stops moving. WnR staff usually 
incentivize students if they are able to appropriately answer their posed question (City of San Jose's Walk n’ Roll Program, 2018). 


\section{School ED's Mode Shift Measures}

*Baseline

N/A: Not Applicable

Reminders:

- The city requires a 20\% mode shift percentage or above after baseline measurement

- $\quad$ Mode Shift $=$ Current Period Percentage - Baseline Percentage $/$ Baseline Percentage

\section{Table 11: School ED Mode Shift Data}

\begin{tabular}{|l|c|c|}
\hline \multicolumn{1}{|c|}{ Season } & $\begin{array}{c}\text { Current Period \% } \\
\text { (Active Transportation) }\end{array}$ & Mode Shift \% \\
\hline *Spring 2012 & $25.5 \%$ & N/A \\
\hline Fall 2012 & $31.2 \%$ & $22.4 \%$ \\
\hline Spring 2013 & $34.5 \%$ & $35.3 \%$ \\
\hline Fall 2013 & $42.3 \%$ & $65.9 \%$ \\
\hline Spring 2014 & $47.3 \%$ & $85.5 \%$ \\
\hline Fall 2014 & $42.1 \%$ & $65.1 \%$ \\
\hline Spring 2015 & $39.7 \%$ & $55.7 \%$ \\
\hline Fall 2015 & $36.9 \%$ & $44.7 \%$ \\
\hline Spring 2016 & $37.0 \%$ & $45.1 \%$ \\
\hline Fall 2016 & $38.2 \%$ & $49.8 \%$ \\
\hline Spring 2017 & $34.7 \%$ & $36.1 \%$ \\
\hline Fall 2017 & $33.7 \%$ & $32.2 \%$ \\
\hline Spring 2018 & $35.8 \%$ & $60.4 \%$ \\
\hline Fall 2018 & $41.2 \%$ & $61.6 \%$ \\
\hline
\end{tabular}


Figure 9: School ED Mode Shift

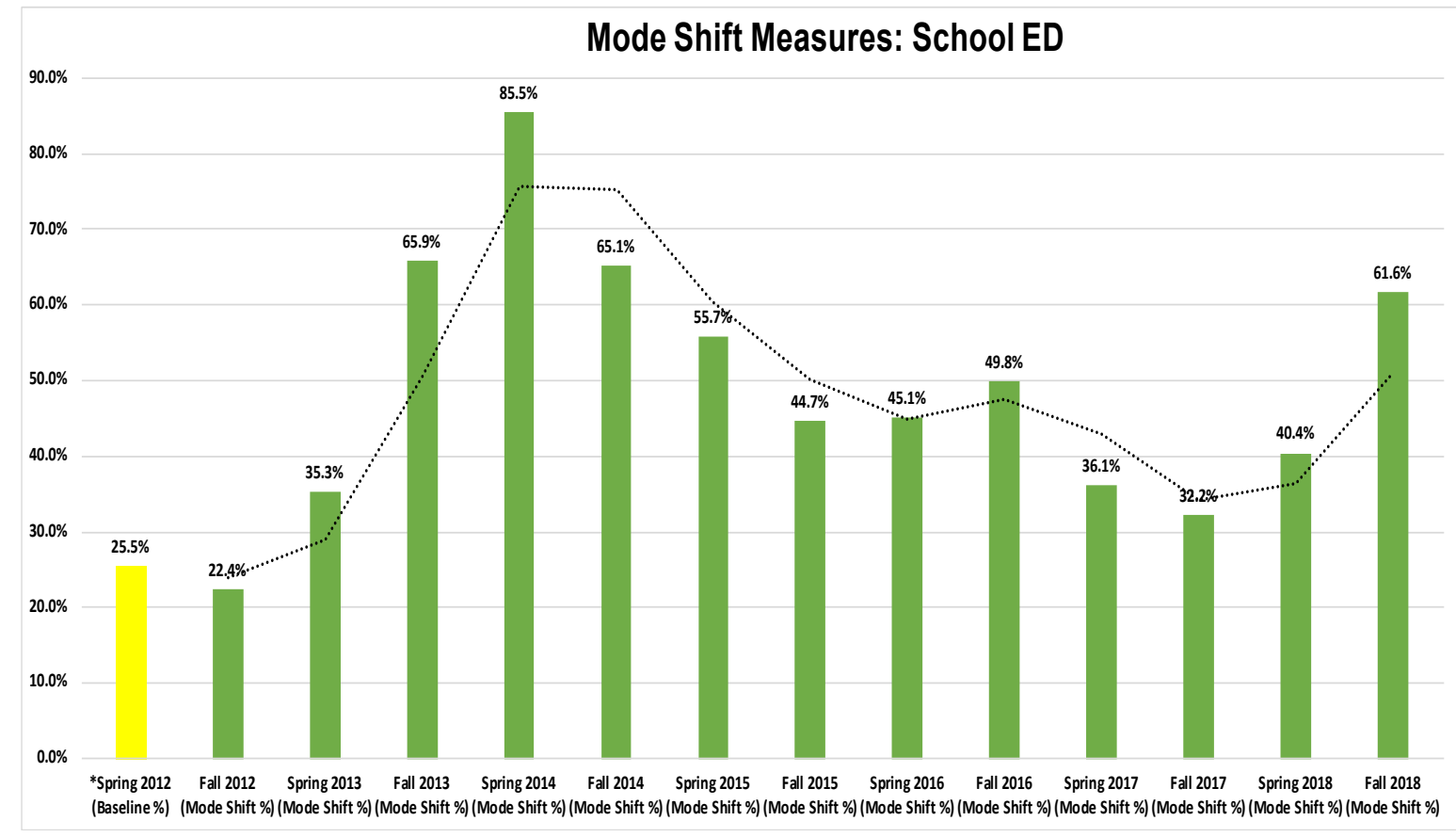

Source: City of San Jose's Walk n' Roll Program, 2018 


\section{School DG}

Table 12: School DG Student Tally Measures Data

\begin{tabular}{|l|c|c|c|c|c|}
\hline \multicolumn{1}{|c|}{ Season } & Population & Walk \% & Bike \% & $\begin{array}{c}\text { Other \% } \\
\text { (Skateboard/Scooter) }\end{array}$ & $\begin{array}{c}\text { Total \% } \\
\text { (Active Transportation) }\end{array}$ \\
\hline Fall 2016 & 347 & $24.0 \%$ & $2.0 \%$ & $0.6 \%$ & $26.6 \%$ \\
\hline Spring 2017 & 308 & $46.0 \%$ & $0 \%$ & $0.7 \%$ & $46.7 \%$ \\
\hline Fall 2017 & 299 & $52.0 \%$ & $0.4 \%$ & $1.0 \%$ & $53.4 \%$ \\
\hline Spring 2018 & 299 & $44.0 \%$ & $0.4 \%$ & $0 \%$ & $44.4 \%$ \\
\hline Fall 2018 & 350 & $40.0 \%$ & $0.7 \%$ & $0.8 \%$ & $41.5 \%$ \\
\hline
\end{tabular}

Figure 10: School DG Student Tally Measures

\section{School DG}

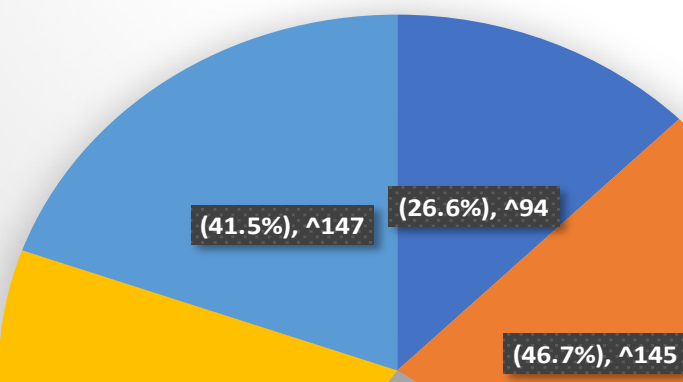

\section{Clarification}

*Total School Population

(Number): Total Percentage of Active Commuters $\wedge$ Number of Active Commuters

a Fall $2016 * 347$

- Spring $2017 * 308$

Fall $2017 * 299$

Spring $2018 * 299$

a Fall $2018 * 350$

(44.4\%), 1132

(53.4\%), 1158

Source: City of San Jose's Walk n' Roll Program, 2018 


\section{School DG Graphic Analysis}

Figure 10 analyzes how School DG has been able to increase the number of their students who actively travel to and from school. Since joining the WnR program and promoting active transportation in Fall 2016, School DG has been able to augment the number of their active commuters by an additional 13 students $(51+13-26+15$ divided by 4$)$ on average every season. In Spring 2017, they added 51; Fall 2017 added 13; Spring 2018 lost 26; and Fall 2018 added 15. During School DG's second season in the WnR program, the school was able to achieve a $46.7 \%$ in their student tally measure, with a total of 145 students who were actively commuting to and from school. The school achieved its greatest success in the percentage of their students of actively commuted to and from school after the first year of their enrollment during the Fall of 2017.

School DG was able to increase the number of their students who actively traveled to and from school to $64(158$ - 94) with a $53.4 \%$ compared to a $27 \%$ percentage from their baseline measurement after the Fall of 2017. The school suffered a decrease of $26(132-158)$ in Spring 2018 from their previous season's measurement (Fall 2017). During the Fall of 2018, School DG was able to achieve an increase of $15(147-132)$ in active commuters from their Spring 2018 tally measure. 


\section{School DG Strategies for Achieving and Sustaining Success}

School DG is one of the few WnR participating schools that strives to integrate active transportation and traffic safety into most of their school's events. The school hosts Walk to School Day every Wednesday, and they kick off their events on the first week of school. To advertise WnR and promote active transportation, School DG uses its school website to educate students and parents about the mission of the WnR program and the benefits of walking and biking to school. School DG champions the program by allowing city staff to inform their community about traffic safety and active transportation through school meetings with the principal, back to school night events, and other community events with parents.

WnR staff members attend School DG consistently throughout their time frame in the program to promote active transportation and traffic safety education. The school has conducted a safety assembly since they have joined the program, and they are on track to organize another one in Spring 2019 (City of San Jose's Walk n' Roll Program, 2018). The school typically hosts a bike rodeo annually, with more than $50 \%$ of their student population participating (City of San Jose's Walk n' Roll Program, 2018). School DG has an established WnR Committee with at least three members (City of San Jose's Walk n' Roll Program, 2018). The school encourages and supports their student population in walking and biking to school by establishing and sustaining 2 walking school buses, with the supervision of their WnR Committee every week (City of San Jose's Walk n' Roll Program, 2018). 
*Baseline

N/A: Not Applicable

Reminders

- The city requires a 20\% mode shift percentage or above after baseline measurement

- $\quad$ Mode Shift $=$ Current Period Percentage - Baseline Percentage $/$ Baseline Percentage

Table 13: School DG Mode Shift Data

\begin{tabular}{|l|c|c|}
\hline \multicolumn{1}{|c|}{ Season } & $\begin{array}{c}\text { Current Period \% } \\
\text { (Active Transportation) }\end{array}$ & Mode Shift \% \\
\hline *Fall 2016 & $26.6 \%$ & N/A \\
\hline Spring 2017 & $46.7 \%$ & $75.6 \%$ \\
\hline Fall 2017 & $53.4 \%$ & $100.8 \%$ \\
\hline Spring 2018 & $44.4 \%$ & $66.9 \%$ \\
\hline Fall 2018 & $41.5 \%$ & $56.0 \%$ \\
\hline
\end{tabular}


Figure 11: School DG Mode Shift

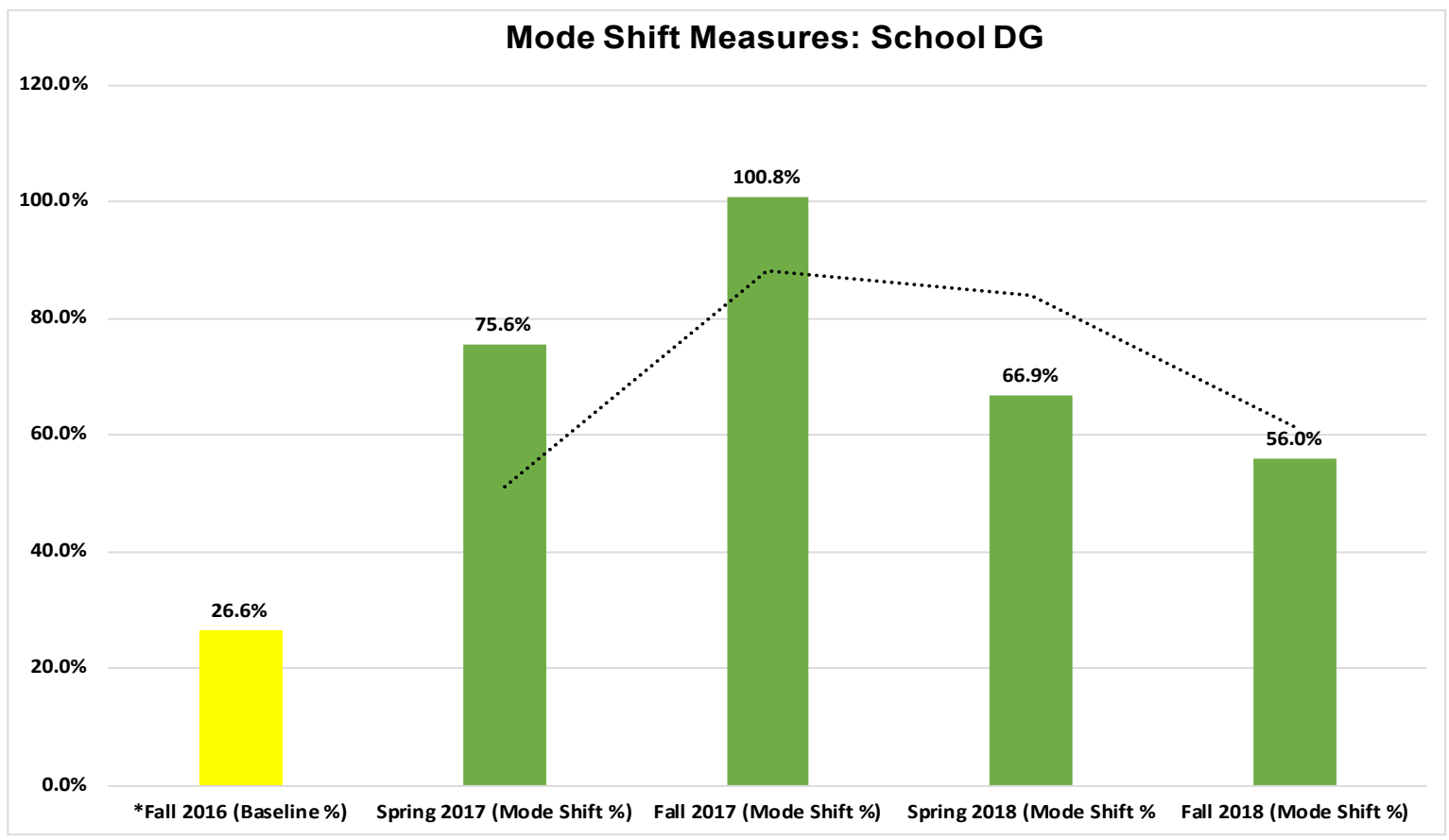

Source: City of San Jose's Walk n' Roll Program, 2018 


\section{School CH}

Table 14: School CH Student Tally Measures Data

\begin{tabular}{|l|c|c|c|c|c|}
\hline \multicolumn{1}{|c|}{ Season } & Population & Walk \% & Bike \% & $\begin{array}{c}\text { Other \% } \\
\text { (Skateboard/Scooter) }\end{array}$ & $\begin{array}{c}\text { Total \% } \\
\text { (Active Transportation) }\end{array}$ \\
\hline Fall 2016 & 666 & $21.0 \%$ & $0.2 \%$ & $0.2 \%$ & $21.4 \%$ \\
\hline Spring 2017 & 600 & $39.0 \%$ & $0.3 \%$ & $0.7 \%$ & $40.0 \%$ \\
\hline Fall 2017 & 588 & $36.0 \%$ & $0.2 \%$ & $0.3 \%$ & $36.5 \%$ \\
\hline Fall 2018 & 590 & $37.0 \%$ & $4.0 \%$ & $1.1 \%$ & $42.1 \%$ \\
\hline
\end{tabular}

Figure 12: School CH Student Tally Measures

\section{School CH}

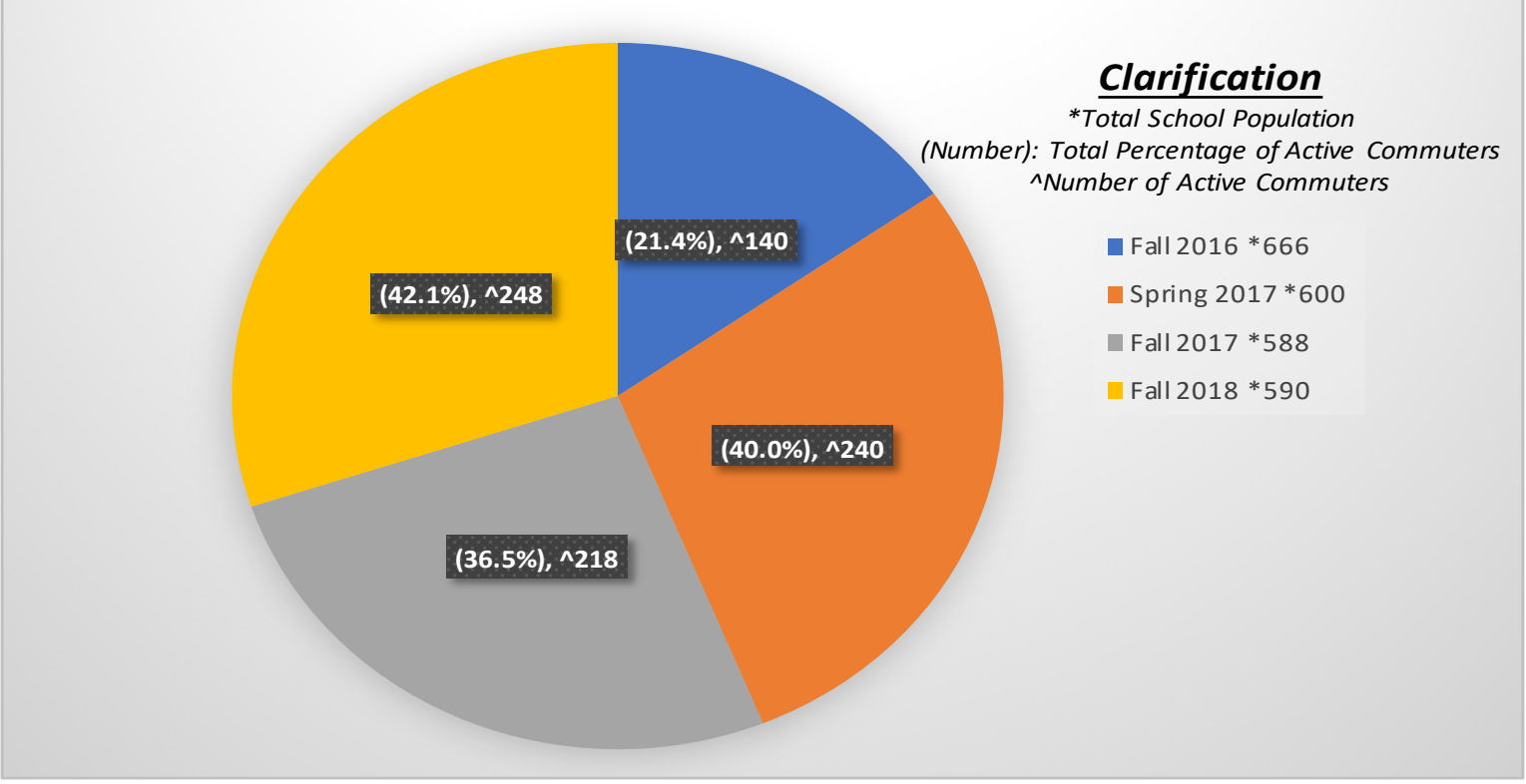

Source: City of San Jose's Walk n' Roll Program, 2018 


\section{School CH Graphic Analysis}

Figure 12 illustrates that School CH joined the program in Fall 2016 with a 21.4\% baseline percentage that included 140 students who were actively traveling to and from school. The school has been able to augment the number of their active commuters by at least 78 students every season from their baseline measurement. In Spring 2017, they added $100(240$ - 100); Fall 2017 added 78 (218 - 140); and Fall 2018 added 108 (248 - 140). The school achieved its greatest increase during the Fall of 2018. Based on figure 12, two of the main reasons that corresponded to the increase in active commuters for School CH during the Fall of 2018, were a decrease of 76 in total school population $(590-666)$ and the school's highest increase in its student tally measure from $21.4 \%$ to $42.1 \%$ during the season (Fall 2018) compared to its baseline measure. 


\section{School CH Strategies for Achieving and Sustaining Success}

School $\mathrm{CH}$ has been championing the WnR program by hosting weekly walk to school days, bike rodeos, and safety assemblies. The school kicks off their walk to school day events on the first week of school, and they have 2 established walking school buses (City of San Jose's Walk n' Roll Program, 2018). School CH has been hosting bike rodeos on a consistent basis since they have joined the program. The school has organized a safety assembly during the first year of their enrollment, to ensure that students received active transportation and traffic safety training. School $\mathrm{CH}$ allows and supports WnR staff in attending yearly school events to promote traffic safety and active transportation. The school has a reliable WnR committee with at least three parent volunteers (City of San Jose's Walk n' Roll Program, 2018). 
*Baseline

N/A: Not Applicable

Reminders

- The city requires a 20\% mode shift percentage or above after baseline measurement

- $\quad$ Mode Shift $=$ Current Period Percentage - Baseline Percentage $/$ Baseline Percentage

Table 15: School CH Mode Shift Data

\begin{tabular}{|l|c|c|}
\hline \multicolumn{1}{|c|}{ Season } & $\begin{array}{c}\text { Current Period \% } \\
\text { (Active Transportation) }\end{array}$ & Mode Shift \% \\
\hline *Fall 2016 & $21.4 \%$ & N/A \\
\hline Spring 2017 & $40.0 \%$ & $86.9 \%$ \\
\hline Fall 2017 & $36.5 \%$ & $70.6 \%$ \\
\hline Fall 2018 & $42.1 \%$ & $96.7 \%$ \\
\hline
\end{tabular}

Figure 13: School CH Mode Shift

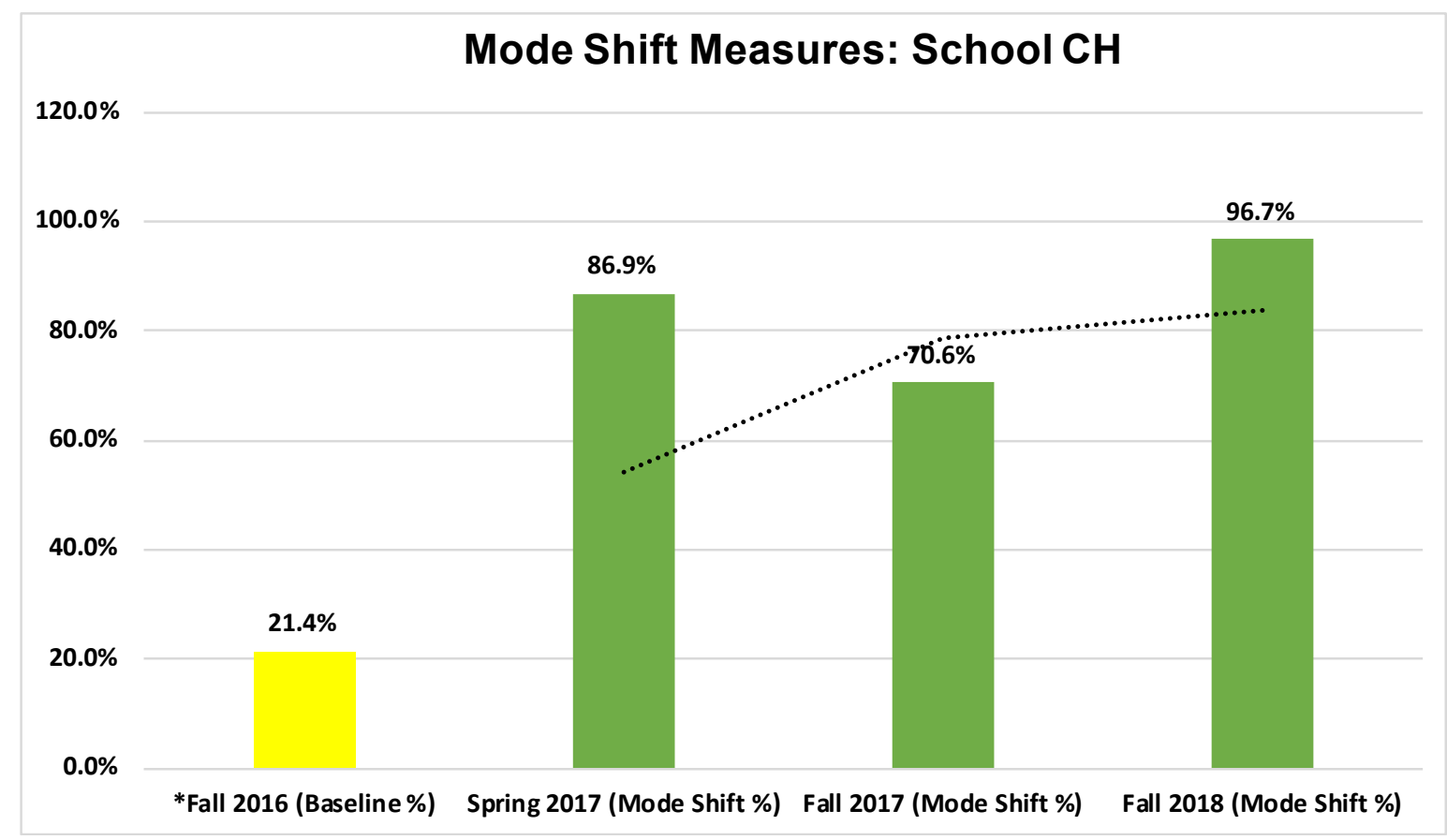

Source: City of San Jose's Walk n’ Roll Program, 2018 
Emissions Savings Evaluation for Schools GA, ED, DG, and CH

Table 16: Schools GA, ED, DG, and CH Transportation Data

\begin{tabular}{|l|c|c|c|c|}
\hline School Name & School District & $\begin{array}{c}\text { Number of Active } \\
\text { Commuters (Baseline) }\end{array}$ & $\begin{array}{c}\text { Number of Active } \\
\text { Commuters } \\
\text { (Fall 2018) }\end{array}$ & $\begin{array}{c}\text { Increase in Number } \\
\text { of Active Commuters }\end{array}$ \\
\hline School GA & Cambrian & 200 & 376 & 176 \\
\hline School ED & Evergreen & 182 & 253 & 71 \\
\hline School DG & Berryessa & 94 & 147 & 53 \\
\hline School CH & Evergreen & 140 & 248 & 108 \\
\hline & & $\mathbf{6 1 6}$ & $\mathbf{1 0 2 4}$ & $\mathbf{4 0 8}$ \\
\cline { 3 - 5 } & & & & \\
\end{tabular}

Increase in Number of Active Commuters $=$ Number of Active Commuters (Fall 2018) -

Number of Active Commuters (Baseline)

Table 17: Calculation for the Number of Vehicle Miles Reduced per Day

\begin{tabular}{|c|c|}
\hline Assumptions & $\begin{array}{l}\text { - New active commuters (Fall 2018) were previously carpooling } \\
\text { - Students actively commuted to and from school ( } 2 \text { trips per day) } \\
\text { - Average car trip distance was reduced by } 1 \text { mile }\end{array}$ \\
\hline Formula & $\begin{array}{l}\text { - Increase in Number of Active Commuters X .75 Carpool Factor X } 2 \\
\text { Trips/Day X 1-Mile Trip }\end{array}$ \\
\hline Calculation & $\begin{array}{l}408 \text { (increase in number of active commuters) } \times .75 \text { (carpool factor) } \times 2 \\
\text { (trips/day) } 21 \text { (mile per trip) } \\
408 \times .75 \times 2 \times 1=612 \text { miles }\end{array}$ \\
\hline Vehicle & - 612 Vehicle Miles Reduced per Day \\
\hline
\end{tabular}


Table 18: Calculation for the Number of Vehicle Miles Reduced for One-Year

\begin{tabular}{|c|c|}
\hline Assumptions & $\begin{array}{l}\text { - Active commuters actively traveled to school } 3 \text { days/week } \\
\text { - } 8 \text { Months School Year or } 32 \text { Weeks }\end{array}$ \\
\hline Formulas & $\begin{array}{l}\text { 1. Number of Weeks X Number of Days Active Commuters Actively } \\
\text { Traveled/Week = Total Days Actively Commuted per School Year } \\
\text { 2. Vehicle Miles Reduced/Day X Number of Days Actively Commuted per } \\
\text { School Year = Total Miles Reduced per School Year }\end{array}$ \\
\hline Calculations & $\begin{array}{l}\text { 1. } 32 \text { (weeks) x } 3 \text { (days commuted/week) = 96 Days Commuted per School } \\
\text { Year } \\
\text { 2. } 612 \text { (miles reduced per day) X } 96 \text { (days commuted per school year) }=58,752 \\
\text { Miles }\end{array}$ \\
\hline Vehicle & - 58,752 Miles Reduced per School Year \\
\hline
\end{tabular}


Table 19: Calculation for Total Gallons of Fuel Saved for One-Year

\begin{tabular}{|c|c|}
\hline Assumption & - Average Vehicle MPG was 21 \\
\hline Gallons Saved per Day & $\begin{array}{c}\text { - Vehicle Miles Reduced per Day / } 21 \mathrm{MPG} \\
\text { • } 612 \text { / } 21 \mathrm{MPG}=29\end{array}$ \\
\hline Gallons Saved Annually & $\begin{array}{c}\text { - Vehicle Miles Reduced per Year / } 21 \mathrm{MPG} \\
\text { - } 58,752 / 21 \mathrm{MPG}=2798\end{array}$ \\
\hline Gallons Saved Annually & - 2,798 Gallons Annually \\
\hline
\end{tabular}

Overall: 408 active commuters $x .75$ carpool factor $x 2$ trips per day $x$ 1-mile trip / 21 MPG x 96 days per year $=2,798$ Gallons Saved Annually 
Measurement from the United States' Environmental Protection Agency

Figure 14: Schools GA, ED, DG, and CH Greenhouse Gas Emissions Savings

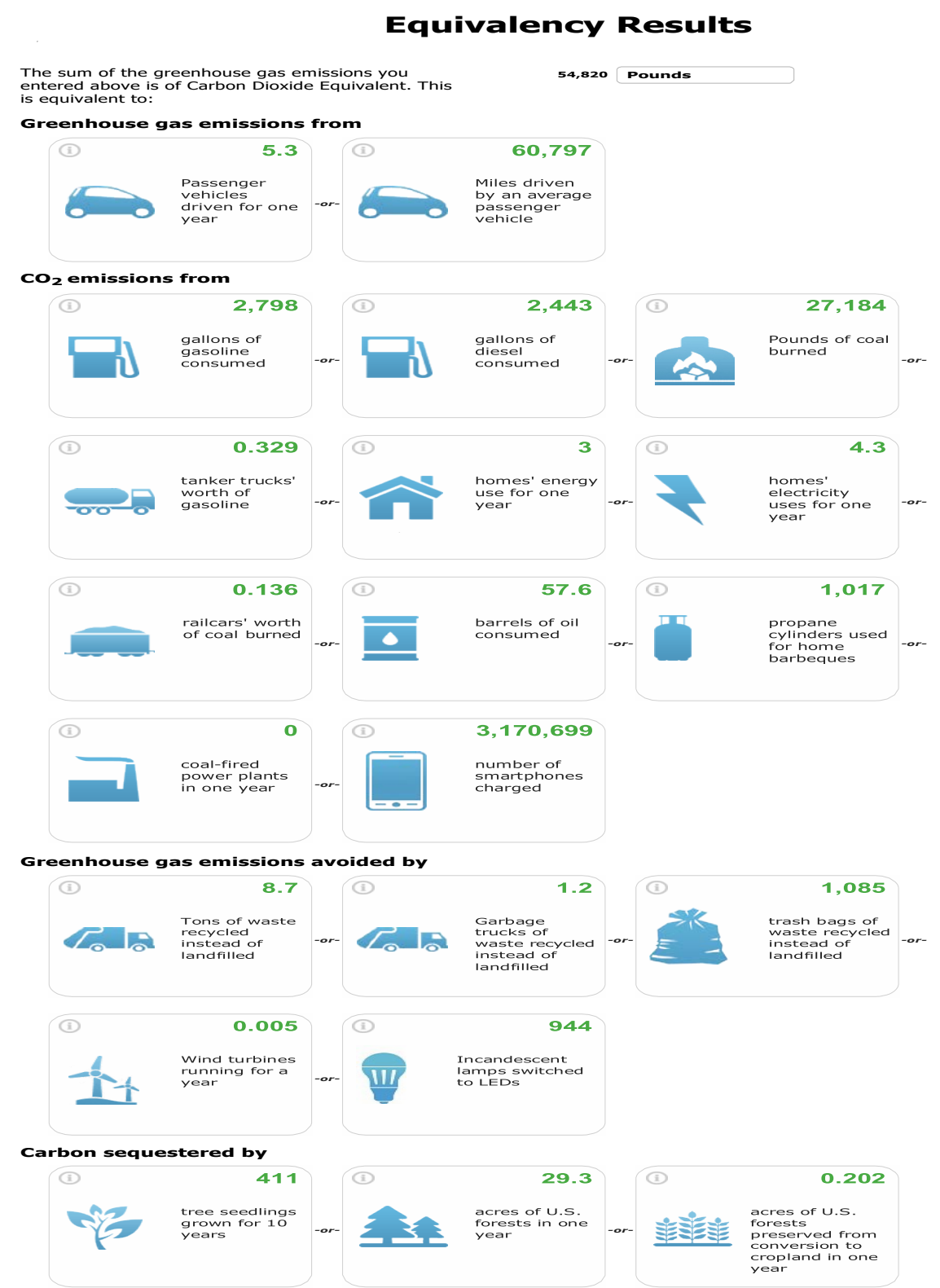

Source: United States' Environmental Protection Agency, 2019 
Figure 14 demonstrates that Schools GA, ED, DG, and CH helped reduce over 54,000 pounds of carbon dioxide with a total increase of 408 students in their school total population who were actively commuting to and from school in 2018 . 


\section{Schools with the Least WnR Success Rate}

Table 20: Schools with Lowest Active Transportation Percentage

\begin{tabular}{|l|c|c|c|}
\hline \multicolumn{1}{|c|}{ School Name } & School District & Baseline Year & Fall 2018 \\
\hline School $1\left(1^{\text {st }}\right)$ & Evergreen & Spring 2016 & $9.8 \%$ \\
\hline School $2\left(2^{\text {nd }}\right)$ & Mount Pleasant & Fall 2012 & $10.1 \%$ \\
\hline School $3\left(3^{\text {rd }}\right)$ & San Jose Unified & Spring 2018 & $10.3 \%$ \\
\hline School $4\left(4^{\text {th }}\right)$ & Berryessa Union & Spring 2012 & $11.0 \%$ \\
\hline School $5\left(5^{\text {th }}\right)$ & Campbell Union & Fall 2012 & $13.1 \%$ \\
\hline School $6\left(6^{\text {th }}\right)$ & Evergreen & Spring 2016 & $14.2 \%$ \\
\hline School $7\left(7^{\text {th }}\right)$ & Mount Pleasant & Fall 2012 & $16.5 \%$ \\
\hline School $8\left(8^{\text {th }}\right)$ & Evergreen & Fall 2015 & $17.2 \%$ \\
\hline School $9\left(9^{\text {th }}\right)$ & Berryessa Union & Fall 2013 & $19.3 \%$ \\
\hline School $10\left(10^{\text {th }}\right)$ & Moreland & Spring 2012 & $22.0 \%$ \\
\hline
\end{tabular}

Source: City of San Jose's Walk n’ Roll Program, 2018

\section{Table 20 Analysis}

Table 20 demonstrates that the lowest 10 schools that had the least children walking, biking, or using other active means to travel to and from school throughout the Fall of 2018 were from Evergreen School District, Mount Pleasant School District, San Jose Unified School District, Berryessa Union School District, Campbell Union School District, and Moreland School District. Although School 1 and School 2 are located in a WnR District Wide area, both institutions had the lowest percentage in active transportation for WnR during the Fall of 2018; School 1, Evergreen School District (9.8\% and $1^{\text {st }}$ place) and School 2, Mount Pleasant School District (10.1\% and $2^{\text {nd }}$ place). Evergreen School District also had two other schools that fell on the list, School 6 (14.2\% and $6^{\text {th }}$ place) and School 8 (17.2\% and $8^{\text {th }}$ place). Mount Pleasant School District was again represented in $7^{\text {th }}$ place, with School 7 achieving a $16.5 \%$. School $3(10.3 \%)$, came in $3^{\text {rd }}$ place representing San Jose Unified School District. Berryessa Union School District was represented by School 4 (11\% and $4^{\text {th }}$ place $)$ and School 9 (19.3\% and $9^{\text {th }}$ place $)$. Campbell 
Union School District fell in $5^{\text {th }}$ place, with School 5 achieving a $13.1 \%$. School 10 came in $10^{\text {th }}$ place, representing Moreland School District with 22\% of its school total population who walked, cycled, or used other means to commute to and from school. 
Table 21: Schools with Lowest Mode Shift Percentage

\begin{tabular}{|l|c|c|c|}
\hline \multicolumn{1}{|c|}{ School Name } & School District & Baseline Year & Fall 2018 \\
\hline School 1 $\left(1^{\text {st }}\right)$ & Mount Pleasant & Fall 2012 & $-45.1 \%$ \\
\hline School $2\left(2^{\text {nd }}\right)$ & Berryessa Union & Fall 2013 & $-39.7 \%$ \\
\hline School 3 $\left(3^{\text {rd }}\right)$ & Evergreen & Fall 2015 & $-27.1 \%$ \\
\hline School $4\left(4^{\text {th }}\right)$ & Berryessa Union & Fall 2012 & $-20.5 \%$ \\
\hline School $5\left(5^{\text {th }}\right)$ & Evergreen & Fall 2017 & $-18.5 \%$ \\
\hline School $6\left(6^{\text {th }}\right)$ & Evergreen & Spring 2016 & $-18.3 \%$ \\
\hline School $7\left(7^{\text {th }}\right)$ & Evergreen & Spring 2016 & $-14.8 \%$ \\
\hline School $8\left(8^{\text {th }}\right)$ & Oak Grove & Fall 2017 & $-11.6 \%$ \\
\hline School $9\left(9^{\text {th }}\right)$ & Luther Burbank & Fall 2017 & $-11.2 \%$ \\
\hline School 10 $\left(10^{\text {th }}\right)$ & San Jose Unified & Fall 2017 & $-10.3 \%$ \\
\hline
\end{tabular}

Source: City of San Jose's Walk n' Roll Program, 2018

\section{Table 21 Analysis}

Table 21 illustrates that Mount Pleasant School District, Berryessa Union School District, Evergreen School District, Oak Grove School District, Luther Burbank School District, and San Jose Unified School District were the regions that had at least a school who was not able to succeed in meeting the city's 20\% mode shift requirement. Evergreen School District had the most schools on the list (4); School 3 (-27.1\% and $3^{\text {rd }}$ place), School $5\left(-18.5 \%\right.$ and $5^{\text {th }}$ place), School $6\left(-18.3 \%\right.$ and $6^{\text {th }}$ place $)$, and School $7\left(-14.8 \%\right.$ and $7^{\text {th }}$ place $)$. School $1\left(1^{\text {st }}\right.$ place $)$ represented Mount Pleasant School District with the least success, a $-45.1 \%$ mode shift percentage. Berryessa Union School District was placed in $2^{\text {nd }}$ and $4^{\text {th }}$ by School $2(-39.7 \%)$ and School 4 (-20.5\%). Oak Grove School District came in $7^{\text {th }}$ place with a $-11.6 \%$ from School 7 . Luther Burbank School District and San Jose Unified School District were the last two areas represented on the list by School $9\left(-11.2 \%\right.$ and $9^{\text {th }}$ place $)$ and School $10\left(-10.3 \%\right.$ and $10^{\text {th }}$ place $)$. 
Table 22: Schools Under Both Standards (Low Active Transportation/Low Mode Shift \%)

\begin{tabular}{|c|c|c|c|c|}
\hline $\begin{array}{c}\text { School } \\
\text { Name }\end{array}$ & School District & $\begin{array}{c}\text { Baseline } \\
\text { Year }\end{array}$ & $\begin{array}{c}\text { Name Under } \\
\text { Table 20 }\end{array}$ & $\begin{array}{c}\text { Name Under } \\
\text { Table 21 }\end{array}$ \\
\hline School 21 & Mount Pleasant & Fall 2012 & School 2 & School 1 \\
\hline School 92 & Berryessa Union & Fall 2013 & School 9 & School 2 \\
\hline School 83 & Evergreen & Fall 2015 & School 8 & School 3 \\
\hline School 16 & Evergreen & Spring 2016 & School 1 & School 6 \\
\hline
\end{tabular}

Schools 1, 2, 3, and 6 from table 21 were also on the list that illustrated the lowest 10 schools that had the least children who actively commuted to and from school during the Fall of 2018 (table 20). Table 22 combines the numbers of all four schools from their name on table 20 and 21 to create a new name for their classification for the category of "Schools Under Both Standards (Low Active Transportation/Low Mode Shift \%)." School 21 started the WnR program with an $18.4 \%$ baseline percentage and currently has a $10.1 \%$ percentage. The school has only achieved a $20 \%$ or higher mode shift percentage once throughout their enrollment time in the program;

31.5\%, and it was in Spring 2017 (City of San Jose's Walk n’ Roll Program, 2018).

School 92 joined the program with a baseline measurement of 32\%. The school's current percentage is $19.3 \%$, and it has never been able to meet the city's mode shift requirement since their enrollment startup, Fall 2013. School 83 decided to establish the culture of the program during the Fall of 2015 with a $23.6 \%$ baseline percentage. The school's current percentage is $17.2 \%$, and it has achieved the city's mode shift requirement twice during its time frame enrolled in the program; Fall 2016 (22.9\%) and Spring 2017 (31.8\%). School 16 registered for the program in Spring 2016 with a $12 \%$ baseline percentage. The school currently has a $9.8 \%$ percentage, and it has never been able to succeed in meeting the city's mode shift requirement (City of San Jose's Walk n' Roll Program, 2018). (See figures 16, 18, 20, and 22 for a mode shift graphic analytic of all four schools; Schools 21, 92, 83, and 16). 
Data/Analysis for Low Active Transportation and Low Mode Shift \% Schools

School 21

Table 23: School 21 Student Tally Measures Data

\begin{tabular}{|l|c|c|c|c|c|}
\hline \multicolumn{1}{|c|}{ Season } & Population & Walk \% & Bike \% & $\begin{array}{c}\text { Other \% } \\
\text { (Skateboard/Scooter) }\end{array}$ & $\begin{array}{c}\text { Total \% } \\
\text { (Active Transportation) }\end{array}$ \\
\hline Fall 2012 & 547 & $17.0 \%$ & $1.0 \%$ & $0.4 \%$ & $18.4 \%$ \\
\hline Fall 2015 & 395 & $15.0 \%$ & $0.4 \%$ & $0.2 \%$ & $15.6 \%$ \\
\hline Spring 2016 & 410 & $20.0 \%$ & $0.3 \%$ & $0.6 \%$ & $20.9 \%$ \\
\hline Fall 2016 & 632 & $13.0 \%$ & $0.1 \%$ & $1.0 \%$ & $14.1 \%$ \\
\hline Spring 2017 & 635 & $24.0 \%$ & $0.2 \%$ & $0 \%$ & $24.2 \%$ \\
\hline Fall 2017 & 632 & $12.0 \%$ & $0.8 \%$ & $0 \%$ & $12.8 \%$ \\
\hline Spring 2018 & 594 & $9.0 \%$ & $0 \%$ & $0.1 \%$ & $9.1 \%$ \\
\hline Fall 2018 & 605 & $10.0 \%$ & $0.1 \%$ & $0 \%$ & $10.1 \%$ \\
\hline
\end{tabular}

Figure 15: School 21 Student Tally Measures

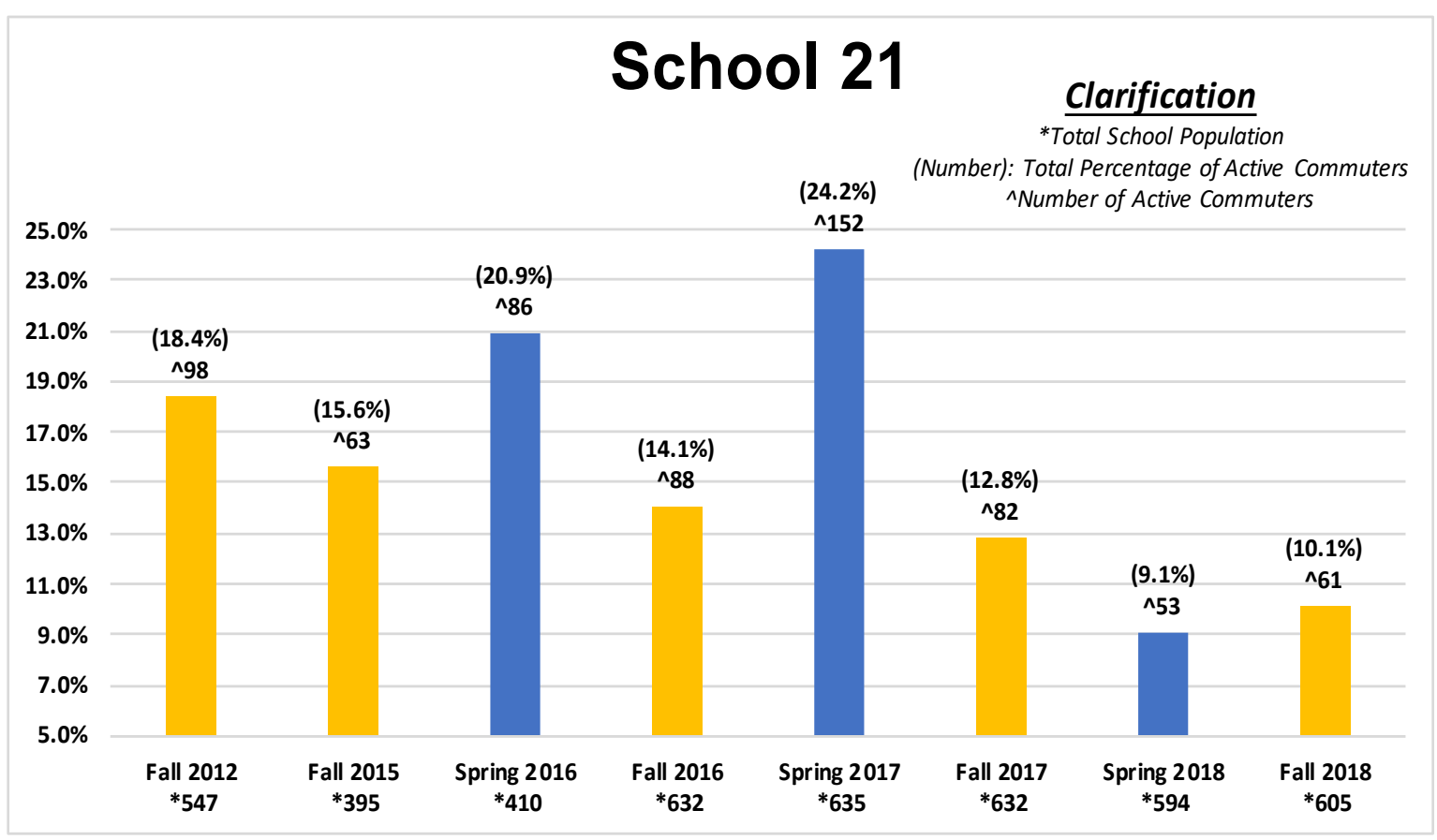

Source: City of San Jose's Walk n’ Roll Program, 2018 


\section{School 21 Graphic Analysis}

Based on figure 15, School 21 has never been able to achieve a percentage of $20 \%$ or more in their student tallies throughout the Fall season. The school has only been able to reach a $20 \%$ or more in the percentage of their students who actively commuted to and from school twice; Spring 2016 (20.9\%) and Spring 2017 (24.2\%). School 21 has failed to surpass the number of their active commuters that corresponds to their baseline measurement throughout most of the seasons that they have been enrolled in the program (except for Spring 2017). The school was only able to increase the number of their students who walked, biked, or used other active means to travel to and from school when they added 54 additional students to their baseline measurement in Spring 2017 (152 - 98). One of the primary reasons for School 21's increase in their total number of active commuters for the Spring of 2017 was an augmentation of 88 additional students $(635-547)$ in the school's population, the largest increase in population for the school throughout its time frame in the $\mathrm{WnR}$ program. 


\section{Reasonings Behind the Failure of School 21}

Since joining the WnR program, School 21 has only hosted walk to school day on a weekly basis for two seasons: Fall 2015 and Spring 2016 (City of San Jose's Walk n’ Roll Program, 2018). The school has failed to consistently conduct safety assemblies and host bike rodeos, to promote active transportation and traffic safety. During the Fall of 2018, the school was not interested in closely working with the WnR program because school representatives were unable to successfully balance the incorporation of traffic safety and active transportation into the school's curriculum. Throughout their enrollment time frame in the program, School 21 has had three different principals (City of San Jose's Walk n' Roll Program, 2018). WnR staff argue that the lack of a stable school administrator may be one of the leading factors that prevent School 21 from successfully instilling the culture of the program into their curriculum. As of right now, School 21 organizes walk to school day on a monthly basis (City of San Jose's Walk n' Roll Program, 2018). 
*Baseline

N/A: Not Applicable

Reminders

- The city requires a 20\% mode shift percentage or above after baseline measurement

- $\quad$ Mode Shift $=$ Current Period Percentage - Baseline Percentage $/$ Baseline Percentage

Table 24: School 21 Mode Shift Data

\begin{tabular}{|l|c|c|}
\hline \multicolumn{1}{|c|}{ Season } & $\begin{array}{c}\text { Current Period \% } \\
\text { (Active Transportation) }\end{array}$ & Mode Shift \% \\
\hline *Fall 2012 & $18.4 \%$ & N/A \\
\hline Fall 2015 & $15.6 \%$ & $-15.2 \%$ \\
\hline Spring 2016 & $20.9 \%$ & $13.6 \%$ \\
\hline Fall 2016 & $14.1 \%$ & $-23.4 \%$ \\
\hline Spring 2017 & $24.2 \%$ & $31.5 \%$ \\
\hline Fall 2017 & $12.8 \%$ & $-30.4 \%$ \\
\hline Spring 2018 & $9.1 \%$ & $-50.5 \%$ \\
\hline Fall 2018 & $10.1 \%$ & $-45.1 \%$ \\
\hline
\end{tabular}


Figure 16: School 21 Mode Shift

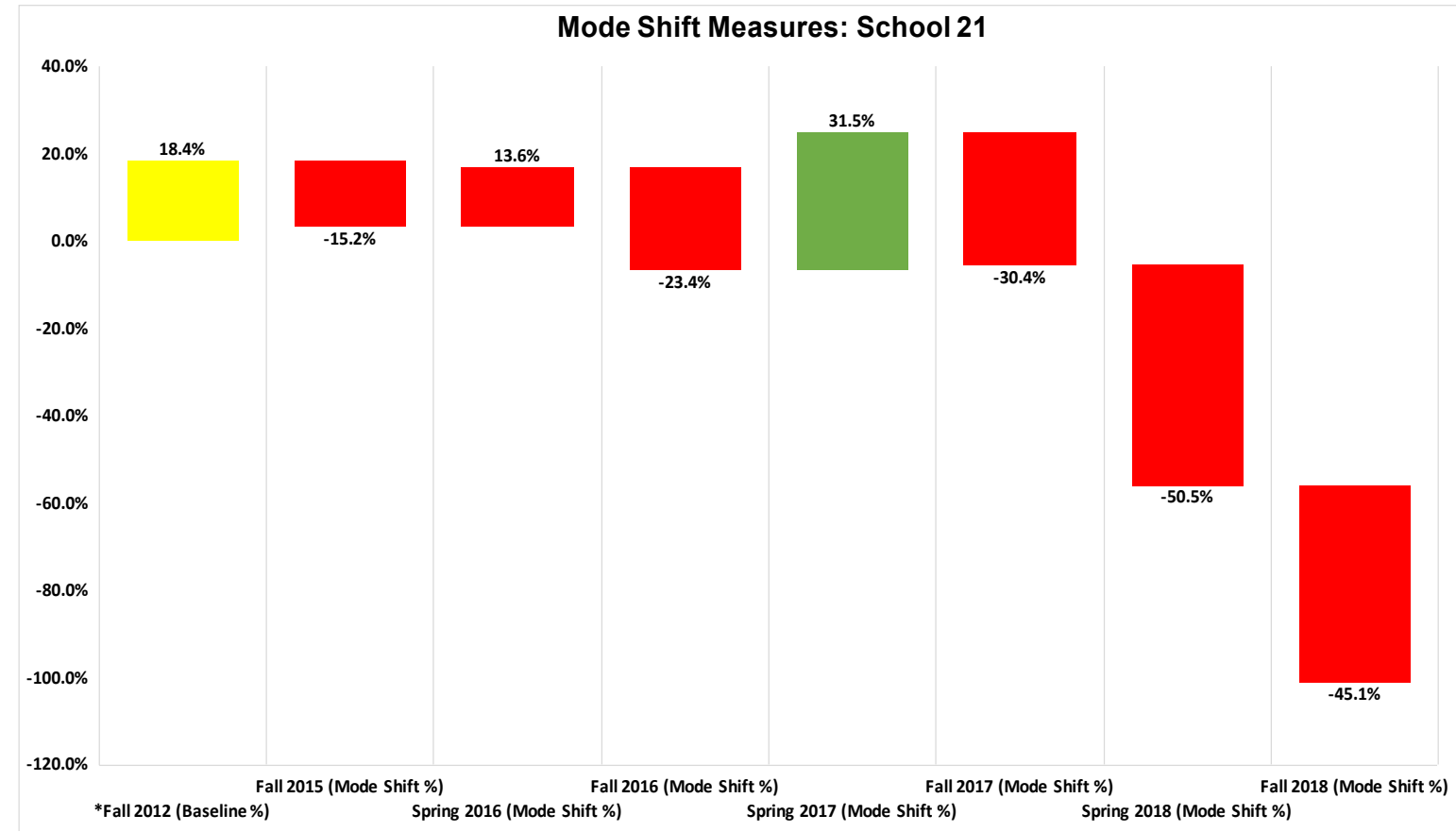

Source: City of San Jose's Walk n' Roll Program, 2018 


\section{School 92}

Table 25: School 92 Student Tally Measures Data

\begin{tabular}{|l|c|c|c|c|c|}
\hline Season & Population & Walk \% & Bike \% & $\begin{array}{c}\text { Other \% } \\
\text { (Skateboard/Scooter) }\end{array}$ & $\begin{array}{c}\text { Total \% } \\
\text { (Active Transportation) }\end{array}$ \\
\hline Fall 2013 & 496 & $30.0 \%$ & $2.0 \%$ & $0 \%$ & $32.0 \%$ \\
\hline Fall 2014 & 446 & $23.0 \%$ & $1.0 \%$ & $0.1 \%$ & $24.1 \%$ \\
\hline Fall 2018 & 380 & $18.0 \%$ & $0.6 \%$ & $0.7 \%$ & $19.3 \%$ \\
\hline
\end{tabular}

Figure 17: School 92 Student Tally Measures

\section{School 92}

\section{Clarification}

*Total School Population

(Number): Total Percentage of Active Commuters ^Number of Active Commuters

\section{(19.3\%), $\wedge 72$}

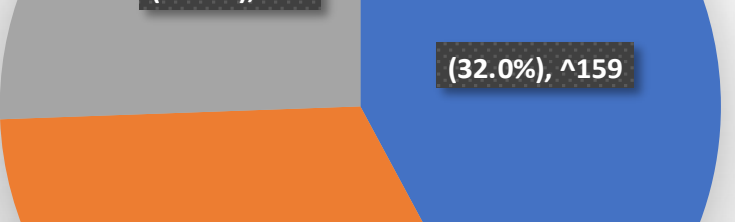

$(24.1 \%), \wedge 107$ صall $2013 * 496$

- Fall $2014 * 446$

- Fall $2018 * 380$

Source: City of San Jose's Walk n’ Roll Program, 2018 


\section{School 92 Graphic Analysis}

It is no surprise that School 92 has never been able to be successful in encouraging its students to actively travel to and from school. Since the implementation of the WnR program, the school has only participated for three seasons: Fall 2013, Fall 2014, and Fall 2018. School 92's current percentage is $19.3 \%$, with a total of 72 students from the school's population of 380 children who actively commute to and from school. Some of the primary factors that have kept School 92 from achieving greater numbers in active transportation are lack of participation and consistent decrease in total school population. Before the Fall of 2018, School 92 failed to engage in the program for 4 years. The school had a decrease that corresponded to 116 students in total population from their baseline measurement $(496$ - 380) during the Fall of 2018. The decrease in school population for School 92 during the Fall of 2018 negatively impacted the school because it led to the highest decline in the percentage and number of active commuters for School 92 throughout their time frame enrolled in the program. 


\section{Reasonings Behind the Failure of School 92}

School 92 has never been able to maintain its enrollment in the WnR for two consecutive seasons since joining the program in Fall 2013 (City of San Jose's Walk n' Roll Program, 2018).

According to WnR staff, school representatives have shown a lack of interest in promoting traffic safety and active transportation. The school has failed to comply with the recommendations and requirements of the WnR program (safety assemblies, bike rodeos, stable relationship with WnR staff to help promote the program through school events, and failure to fully complete yearly student tally surveys). One of the main reasons that the school re-enrolled in the program during the Fall of 2018, was because its district became a WnR School District Wide participant. As of right now, the school organizes walk to school day on a monthly basis (City of San Jose's Walk n' Roll Program, 2018). 
*Baseline

N/A: Not Applicable

Reminders

- The city requires a 20\% mode shift percentage or above after baseline measurement

- $\quad$ Mode Shift $=$ Current Period Percentage - Baseline Percentage $/$ Baseline Percentage

Table 26: School 92 Mode Shift Data

\begin{tabular}{|l|c|c|}
\hline Season & $\begin{array}{c}\text { Current Period \% } \\
\text { Active Transportation) }\end{array}$ & Mode Shift \% \\
\hline *Fall 2013 & $32.0 \%$ & N/A \\
\hline Fall 2014 & $24.1 \%$ & $-24.7 \%$ \\
\hline Fall 2018 & $19.3 \%$ & $-39.7 \%$ \\
\hline
\end{tabular}

Figure 18: School 92 Mode Shift

\section{Mode Shift Measures: School 92}

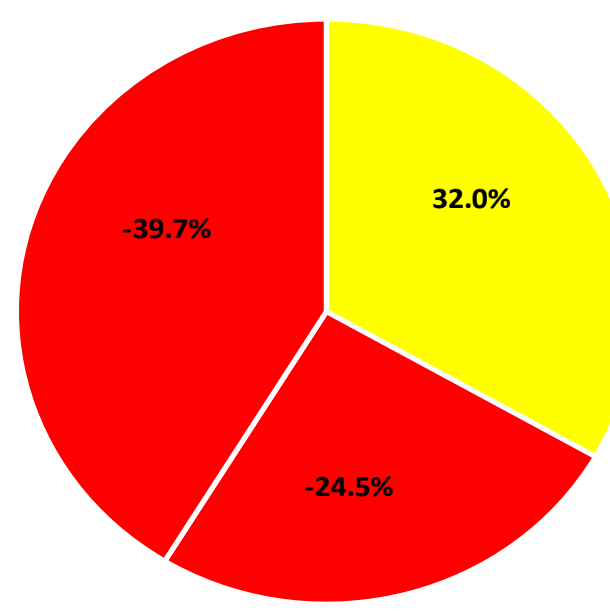

*Fall 2013 (Baseline \%) - Fall 2014 (Mode Shift \%) - Fall 2018 (Mode Shift \%)

Source: City of San Jose's Walk n’ Roll Program, 2018 


\section{School 83}

Table 27: School 83 Student Tally Measures Data

\begin{tabular}{|l|c|c|c|c|c|}
\hline \multicolumn{1}{|c|}{ Season } & Population & Walk \% & Bike \% & $\begin{array}{c}\text { Other \% } \\
\text { (Skateboard/Scooter) }\end{array}$ & $\begin{array}{c}\text { Total \% } \\
\text { (Active Transportation) }\end{array}$ \\
\hline Fall 2015 & 319 & $22.0 \%$ & $0.9 \%$ & $0.7 \%$ & $23.6 \%$ \\
\hline Spring 2016 & 493 & $26.0 \%$ & $0.4 \%$ & $1.0 \%$ & $27.4 \%$ \\
\hline Fall 2016 & 596 & $26.0 \%$ & $2.0 \%$ & $1.0 \%$ & $29.0 \%$ \\
\hline Spring 2017 & 599 & $29.0 \%$ & $0.1 \%$ & $2.0 \%$ & $31.1 \%$ \\
\hline Fall 2017 & 574 & $21.0 \%$ & $1.0 \%$ & $0.9 \%$ & $22.9 \%$ \\
\hline Spring 2018 & 579 & $18.0 \%$ & $0.8 \%$ & $0.3 \%$ & $19.1 \%$ \\
\hline Fall 2018 & 522 & $16.0 \%$ & $0.8 \%$ & $0.4 \%$ & $17.2 \%$ \\
\hline
\end{tabular}

Figure 19: School 83 Student Tally Measures

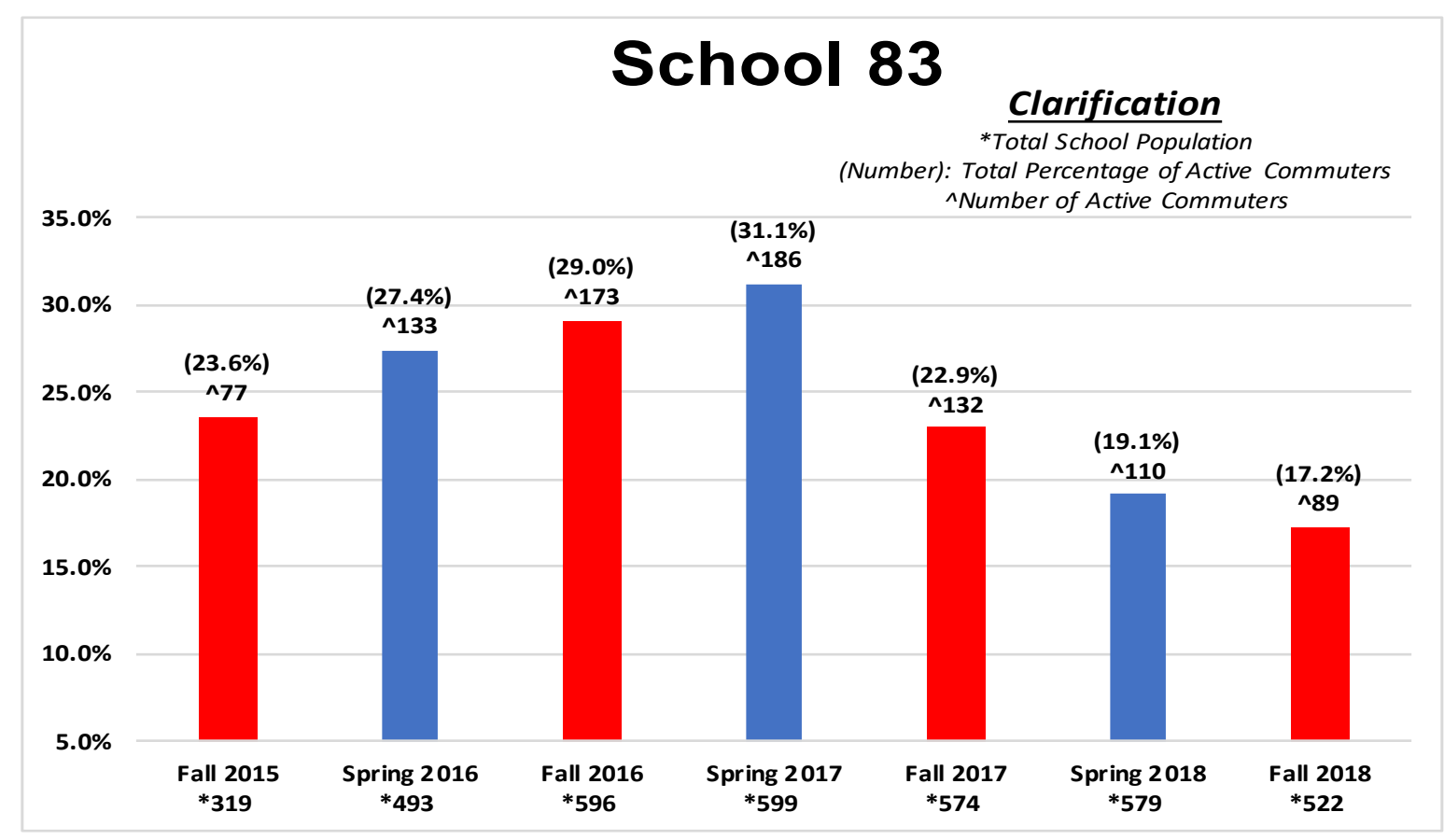

Source: City of San Jose's Walk n' Roll Program, 2018 


\section{School 83 Graphic Analysis}

Based on figure 19, School 83 's greatest success was a 7\% increase in their student tally tracking during the Spring season of 2017 from their baseline measure (31\% - 24\%). The school was able to increase the number of their active commuters to 186 (109 additional students) from 77 (18677). The school has been able to increase the number of their students who walk, bike, or use other active travel alternatives by an additional 12 students every season from their baseline measurement: Spring 2016 added 56 (133 - 77); Fall 2016 added 96 (173 - 77); Spring 2017 added 109 (186 - 77); Fall 2017 added 55 (132 - 77); Spring 2018 added 33 (110 - 77); and Fall 2018 added $12(89-77)$. Although the school has not been able to achieve a significant increase in the percentage of their student tally measures, the level of augmentation on School 83's total school population has allowed the school to increase the number of their active commuters from their baseline measure every season. 


\section{Reasonings Behind the Failure of School 83}

Although School 83 has been able to consistently participate in the WnR program since their enrollment startup, the school has failed to balance promoting traffic safety and active transportation with their educational priorities. The school usually has a late kick-off for their walk to school day events, during International Walk to School Day, and they have never been able to organize their events on a weekly basis for two consecutive seasons (City of San Jose's Walk n' Roll Program, 2018). Since joining the program in Fall 2015, School 83 has had three different principals; therefore, compared to School 21, this matter may be one of the reasons why the school has not been successful in developing the majority of its students into active commuters. School 83 has only conducted 1 Safety Assembly throughout their time frame in the program, and they currently host walk to school day on a monthly basis (City of San Jose's Walk n’ Roll Program, 2018). 


\section{School 83's Mode Shift Measures}

*Baseline

N/A: Not Applicable

Reminders

- The city requires a 20\% mode shift percentage or above after baseline measurement

- $\quad$ Mode Shift $=$ Current Period Percentage - Baseline Percentage $/$ Baseline Percentage

Table 28: School 83 Mode Shift Data

\begin{tabular}{|l|c|c|}
\hline \multicolumn{1}{|c|}{ Season } & $\begin{array}{c}\text { Current Period \% } \\
\text { (Active Transportation) }\end{array}$ & Mode Shift \% \\
\hline *Fall 2015 & $23.6 \%$ & N/A \\
\hline Spring 2016 & $27.4 \%$ & $16.1 \%$ \\
\hline Fall 2016 & $29.0 \%$ & $22.9 \%$ \\
\hline Spring 2017 & $31.1 \%$ & $31.8 \%$ \\
\hline Fall 2017 & $22.9 \%$ & $-3.0 \%$ \\
\hline Spring 2018 & $19.1 \%$ & $-19.1 \%$ \\
\hline Fall 2018 & $17.2 \%$ & $-27.1 \%$ \\
\hline
\end{tabular}


Figure 20: School 83 Mode Shift

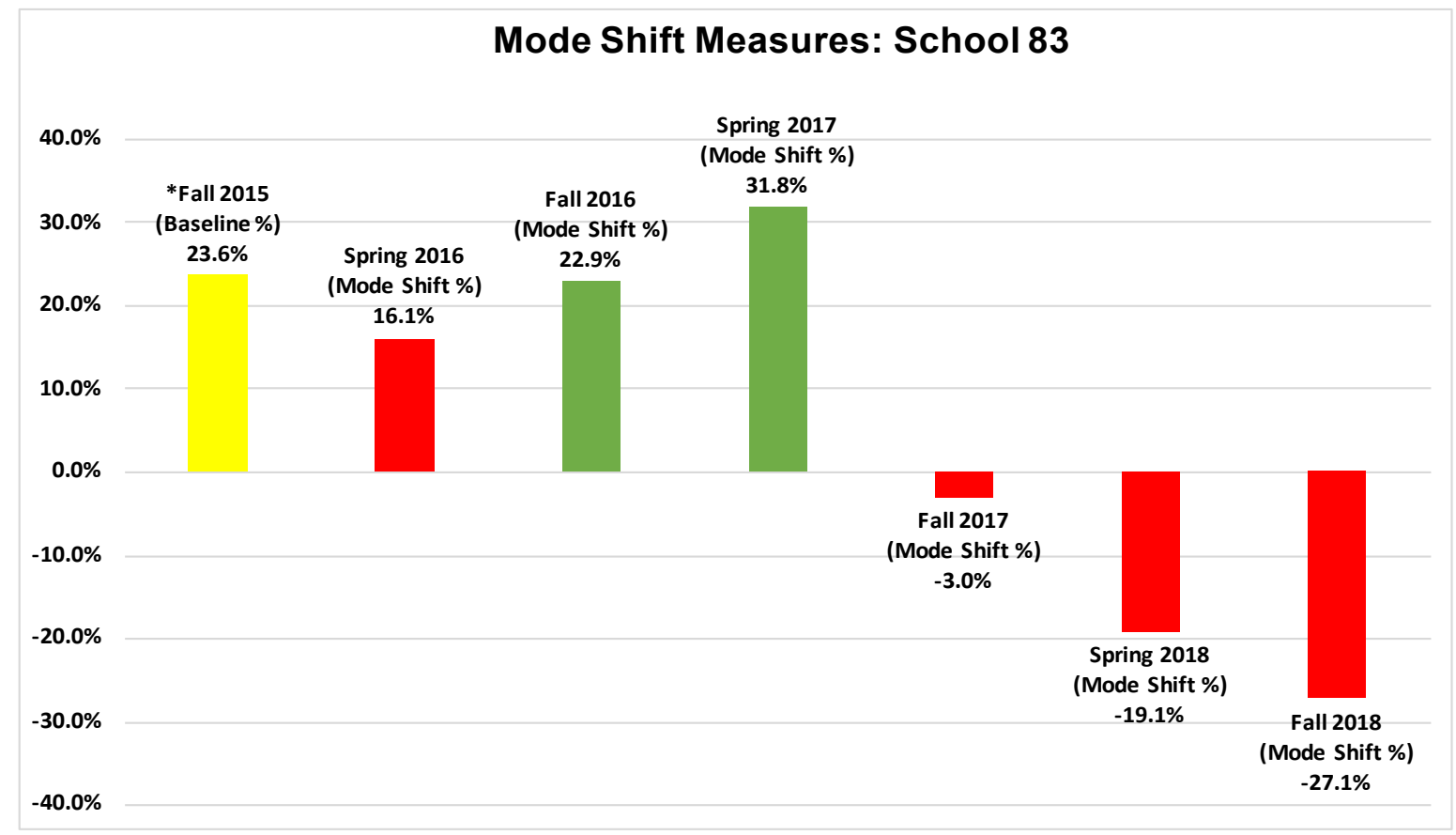

Source: City of San Jose's Walk n' Roll Program, 2018 


\section{School 16}

Table 29: School 16 Student Tally Measures Data

\begin{tabular}{|l|c|c|c|c|c|}
\hline Season & Population & Walk \% & Bike \% & $\begin{array}{c}\text { Other \% } \\
\text { (Skateboard/Scooter) }\end{array}$ & $\begin{array}{c}\text { Total \% } \\
\text { (Active Transportation) }\end{array}$ \\
\hline Spring 2016 & 231 & $11.0 \%$ & $1.0 \%$ & $0 \%$ & $12.0 \%$ \\
\hline Fall 2018 & 300 & $6.0 \%$ & $3.0 \%$ & $0.8 \%$ & $9.8 \%$ \\
\hline
\end{tabular}

Figure 21: School 16 Student Tally Measures

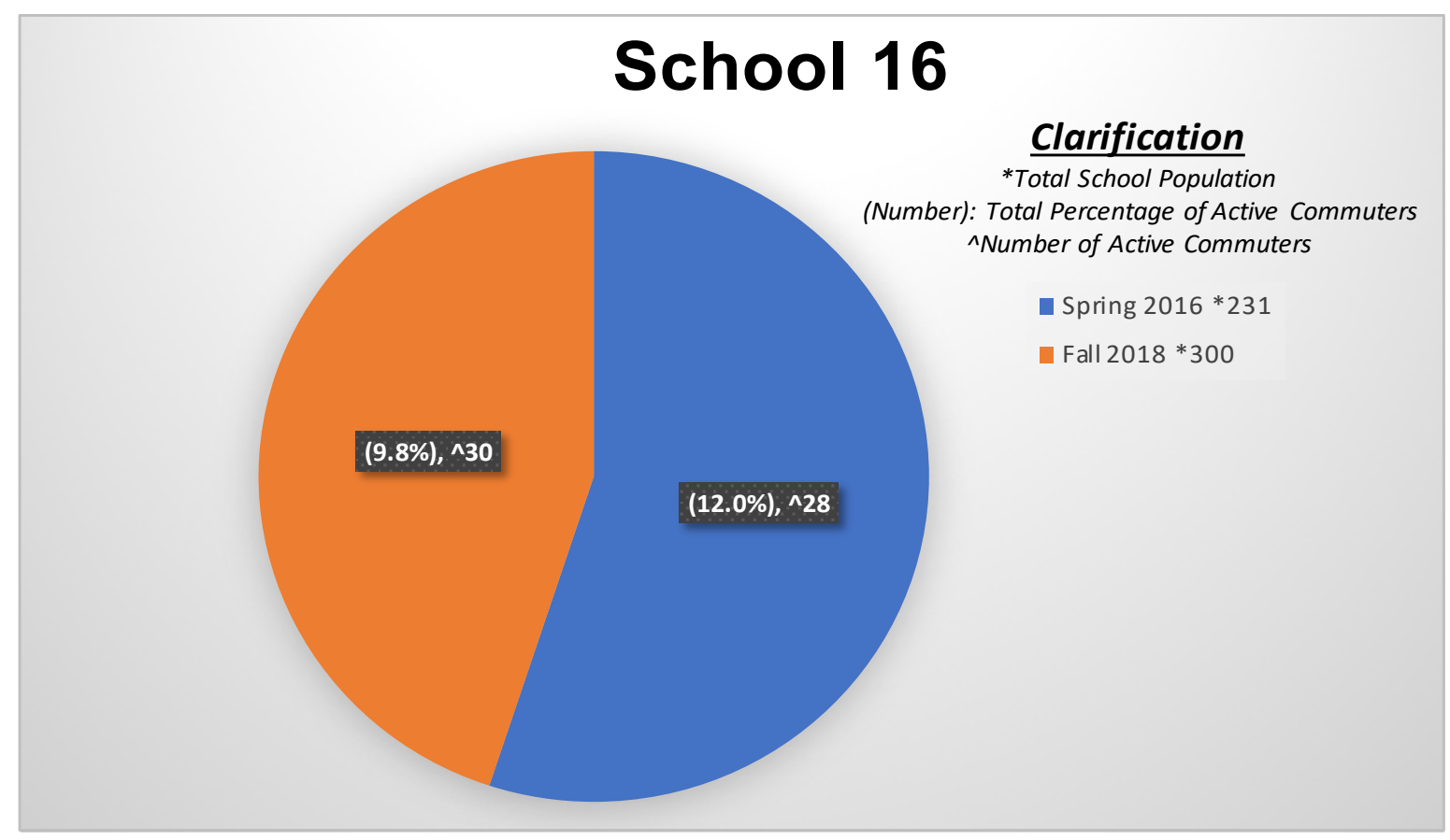

Source: City of San Jose's Walk n’ Roll Program, 2018 


\section{School 16 Graphic Analysis}

Figure 21 illustrates that School 16 has been unsuccessful in promoting active transportation and traffic safety because it has failed to remain enroll in the program for more than two seasons. The school joined WnR 4 years after the city implemented it, and it appears as if the school was never able to establish the culture of the program. The school's current tally measure is $9.8 \%$, with a total of 30 students, from the school's population of 300 children, who actively commute to and from school. School 16 started with a higher active transportation percentage (12\%) when they joined the program in Spring 2016; however, the school had fewer children who were enrolled for school during the baseline time frame of their enrollment startup compared to the institution's 2018 enrollment status. The school had a total of 231 students when they enrolled in Spring 2016. During the Fall of 2018, that number increased to 300 students, 69 additional children (300 - 231). The rise in School 16's total population during the Fall of 2018 led to an increase in active commuters for the school although there was a decrease in the percentage of children who were actively commuting to and from school. 


\section{Reasonings Behind the Failure of School 16}

School 16 has failed to participate in the WnR for more than two seasons; the school has never accomplished a full year of enrollment with the program. School 16 joined the program in Spring 2016 and re-enrolled in Fall 2018 when their district became a WnR School District Wide participant (City of San Jose's Walk n' Roll Program, 2018). School 16 has been unsuccessful in collaborating with WnR staff through school events to promote traffic safety and active transportation. The school has not conducted a safety assembly, and they have never hosted a bike rodeo (City of San Jose's Walk n' Roll Program, 2018). 
*Baseline

N/A: Not Applicable

Reminders

- The city requires a 20\% mode shift percentage or above after baseline measurement

- $\quad$ Mode Shift $=$ Current Period Percentage - Baseline Percentage $/$ Baseline Percentage

Table 30: School 16 Mode Shift Data

\begin{tabular}{|l|c|c|}
\hline \multicolumn{1}{|c|}{ Season } & $\begin{array}{c}\text { Current Period \% } \\
\text { (Active Transportation) }\end{array}$ & Mode Shift \% \\
\hline *Spring 2016 & $12.0 \%$ & N/A \\
\hline Fall 2018 & $9.8 \%$ & $-18.3 \%$ \\
\hline
\end{tabular}

Figure 22: School 16 Mode Shift

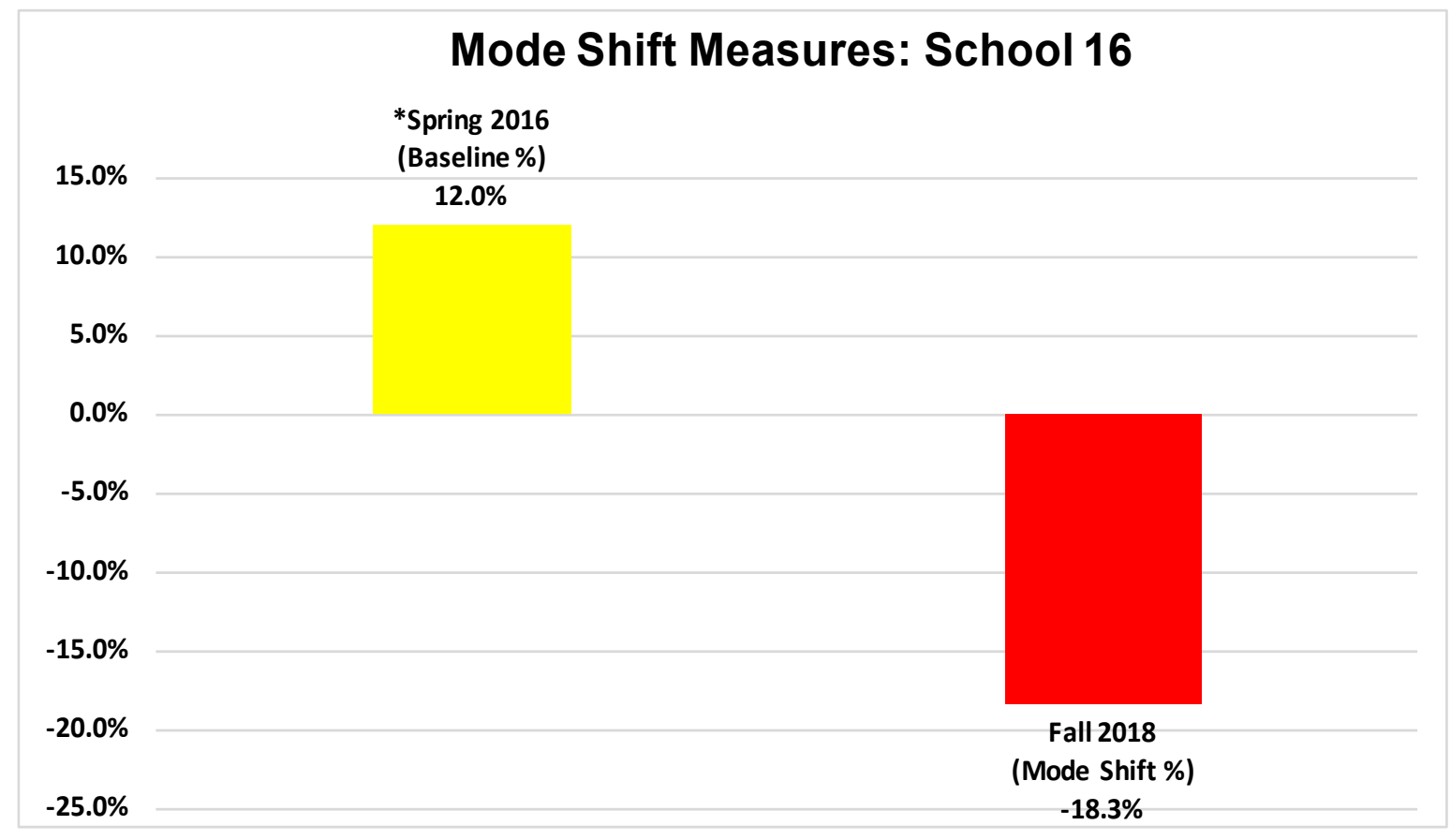

Source: City of San Jose's Walk n’ Roll Program, 2018 


\section{ANALYSIS/CONCLUSION}

\section{Schools with High Active Transportation/High Mode Shift \%}

Overall, one can argue that the WnR program is highly effective in promoting active transportation and traffic safety to school. The program is efficacious with using its current tools and strategies to augment the number of children who actively travel (walk and bike) and use other means such as scooters and skateboards to commute to and from school. Based on the findings of this paper, the four schools that fell under both classifications (High Active Transportation/High Mode Shift \%), were able to achieve and sustain success by actively and committedly incorporating the program's recommendations and technique suggestions into their curriculum.

The four schools that fell under both classifications encouraged and promoted active transportation to their community on a weekly or monthly basis. All four schools used their weekly or monthly walk to school day events as a foundation to familiarize students and their family with active transportation. School administrators from all four schools used either one of the two techniques for promoting active transportation to establish an efficient culture for International Walk to School Day and the remaining days of the school year. In addition, Schools $\mathrm{ED}, \mathrm{DG}$, and $\mathrm{CH}$ hosted all of the events that the program provides on a consistent basis, and they supported WnR staff in attending school events to promote traffic safety and active transportation. School GA did not need to actively host WnR events because it is a middle school, located nearby an elementary participating WnR school, with most of its students transitioning from the elementary school with $\mathrm{WnR}$ already instilled into their culture. Moreover, all four schools have an established WnR committee with at least three volunteers (City of San Jose's Walk n’ Roll Program, 2018). 


\section{How Can All Four Schools Sustain Success?}

All four schools must continue to host $\mathrm{WnR}$ events and promote traffic safety and active transportation as they are doing currently. To improve and sustain success in encouraging active transportation for students attending their institution, school administrators should methodically collaborate with WnR staff and their school committee to refine and alter their active transportation plan on a yearly basis. This approach would consist of limited modifications on the resources that the program provides.

For instance, school administrators should collaborate with their school committee and WnR staff to update the incentive system of the program, and the articulation of traffic safety and active transportation suggestions and recommendations that the program advertises in publication materials. This proposition would benefit all four schools and WnR staff in understanding the need of students for incentive materials that they would prefer. Furthermore, it could increase the enthusiasm level of students about WnR because they would be introduced to new materials annually. The purpose of refining the articulation of traffic safety and active transportation suggestions and recommendations in the materials that the program provides is to help students in enhancing their vocabulary usage and better understand the mission and benefits of active transportation in promoting a better and safer society. 


\section{Schools with Low Active Transportation/Low Mode Shift \%}

Based on the findings of this project, one can argue that the WnR program needs major improvements and a more structured system to systematically and efficiently operate. From analyzing School 21, one can question the level of productiveness for WnR staff members in allowing the school to only host walk to school day events on a weekly basis for only 2 seasons while being enrolled in the program for 8 seasons. In addition, one can argue that it should be unacceptable for a school to be enrolled in the program for 8 seasons and not be able to host WnR events on a consistent basis.

Other findings from this research that connected to the failure of the schools that fell under both classifications (Low Active Transportation/Low Mode Shift \%), were their inability to sustain a stable principal and their low level of desire to collaborate with WnR staff members to promote traffic safety and active transportation. Both School 21 and 83 have had three different principals throughout their time frames enrolled in the program; both schools have been in the program for at least 7 seasons. Moreover, Schools 92 and 16 have been inconsistent in their enrollment in the program. School 92 joined the program in Fall 2013, came back in Fall 2014, and re-enrolled in Fall 2018. School 16 joined the program in Spring 2016 and re-enrolled in Fall 2018. All four schools have not established WnR committees and showed no interest in desiring to promote active transportation and traffic safety during the Fall of 2018. 


\section{How Can the WnR Program Help All Four Schools?}

It is appropriate for schools to not be able to promote active transportation due to other priorities, such as providing exceptional education to students and ensuring that children are meeting and exceeding test requirements. However, one can argue that the WnR program could develop a more rigid and clear guideline to promote its mission. For example, this guideline should be composed of rules and policies that require a certain level of commitment from school administrators. This approach would benefit the program because it would allow schools to understand their due diligence and better comprehend what is expected from them. This suggestion would help school administrators in determining whether WnR is an appropriate plan for their school's curriculum. To help schools retain their enrollment in the program and promote active transportation and traffic safety, WnR staff are collaborating with superintendents from various school districts to make WnR a District Wide required policy. Within the past few months, WnR staff have succeeded in helping Berryessa Union School District, Evergreen School District, and Mount Pleasant School District become WnR School District Wide participants (Street Smarts, 2018). 


\section{Recommendation}

WnR San Jose has the potential to be one of the most effective active transportation plans in the city. If San Jose decides to focus on structuring and effectuating it methodically, the program could significantly increase the level of its effectiveness around elementary and middle schools in San Jose, and possibly expand to the high schools, colleges, and universities. The city could potentially use the program to educate scholars about traffic safety and active transportation with its correlation to the mitigation of global warming and traffic congestion in San Jose.

Future scholars may consider evaluating the route infrastructure around the schools that have not been able to be successful in the WnR program. Their studies can help the City of San Jose to learn about areas that need improvements and possibly strive to restructure San Jose's infrastructure near school zones in a better manner suitable for active transportation. Scholars may also consider another study on the vast majority of students and scholars who reside in San Jose and seek strategies that the City of San Jose could implement into their approach to promote and educate residents about active transportation and traffic safety. 


\section{REFERENCES}

Active Living Research. (2011). School Environment and Active Transportation to School. Retrieved from https://www.activelivingresearch.org/school-environment-and-activetransportation-school-research-summary-slides

Buttazzoni, A., Coen, S., \& Gilliland, J. (2018). Supporting Active School Travel: A Qualitative Analysis of Implementing a Regional Safe Routes to School Program. Social Science \& Medicine, 212, 181-190.

CalTrans Division of Local Assistance. (2018). Safe Routes to School Programs. Retrieved from http://www.dot.ca.gov/hq/LocalPrograms/saferoutes/saferoutes.htm

Chaufan, C., Yeh, J., \& Fox, P. (2012). The Safe Routes to School Program in California: An Update. American Journal of Public Health, 102(6), E8-11.

City of San Jose's Department of Transportation. (2018). Vision Zero San Jose: Two-Year Action Plan - 2017 \& 2018. Retrieved from http://www.sanjoseca.gov/DocumentCenter/View/74828

City of San Jose's Police Department. (2018). School Safety and Education Unit. Retrieved from http://www.sjpd.org/bfo/community/schoolsafety/

City of San Jose's Walk n' Roll Program. (2018). Walk n' Roll San Jose Fall 2018. Retrieved from Walk n' Roll Staff.

Johansson, R. (2009). Vision Zero - Implementing a Policy for Traffic Safety. Safety Science, $47(6), 826-831$.

Johnston, I. (2010). Beyond "Best Practice" Road Safety Thinking and Systems Management A Case for Culture Change Research. Safety Science, 48(9), 1175-1181.

Larouche, R., Mammen, G., Rowe, D., \& Faulkner, G. (2018). Effectiveness of Active School 
Transport Interventions: A Systematic Review and Update. BMC Public Health, 18(1), 206.

Law \& Policy Innovation. (2018). Benefits of Safe Routes to School. Retrieved from https://www.changelabsolutions.org/benefits-safe-routes-school

May, M., Tranter, P., \& Warn, J. (2011). Progressing Road Safety Through Deep Change and Transformational Leadership. Journal of Transport Geography, 19(6), 1423-1430.

Mcdonald, N., Steiner, R., Palmer, W., Bullock, A., Sisiopiku, V., \& Lytle, B. (2016). Costs of School Transportation: Quantifying the Fiscal Impacts of Encouraging Walking and Bicycling for School Travel. Transportation, 43(1), 159-175.

Mees, P., O'Connell, G., \& Stone, J. (2008). Travel to Work in Australian Capital Cities, 19762006. Urban Policy and Research, 26(3), 363-378.

Muennig, P., Epstein, M., Li, G., \& Dimaggio, C. (2014). The Cost-Effectiveness of New York City's Safe Routes to School Program. American Journal of Public Health, 104(7), 1294 9.

Nicholson, L., Turner, L., Slater, S., Abuzayd, H., Chriqui, J., \& Chaloupka, J. (2014). Developing a Measure of Traffic Calming Associated with Elementary School Students' Active Transport. Transportation Research Part D, 33, 17-25.

Panter, J., Jones, A., Sluijs, E., \& Griffin, S. (2009). Attitudes, Social Support and Environmental Perceptions as Predictors of Active Commuting Behavior in School Children. Journal of Epidemiology and Community Health, 64(1), 41-8.

Ross, A., Rodríguez, A., \& Searle, M. (2017). Associations Between the Physical, Sociocultural, and Safety Environments and Active Transportation to School. American Journal of Health Education, 48(3), 198-209. 
Street Smarts, City of San Jose. (2014). Walk n' Roll San Jose. Retrieved from http://www.getstreetsmarts.org/walknroll/

Street Smarts, City of San Jose. (2018). Walk n' Roll San Jose. Retrieved from http://www.getstreetsmarts.org/walknroll/

Sylvia, R., \& Sylvia, K. Program Planning and Evaluation for the Public Manager, 4th Edition. (Waveland Press, 2012).

Tranter, P. (2010). Speed Kills: The Complex Links Between Transport, Lack of Time and Urban Health. Journal of Urban Health, 87(2), 155-166.

United States' Environmental Protection Agency. (2019). Emissions Savings. Retrieved from https://www.epa.gov/energy/greenhouse-gas-equivalencies-calculator

U.S. Department of Health and Human Services. (2017). Importance of Physical Activity. Retrieved from https://www.hhs.gov/fitness/be-active/importance-ofphysicalactivity/index.html

Vadeby, A., \& Forsman, A. (2018). Traffic Safety Effects of New Speed Limits in Sweden. Accident Analysis and Prevention, 114, 34-39.

Wojan, T., \& Hamrick, K. (2015). Can Walking or Biking to Work Really Make a Difference? Compact Development, Observed Commuter Choice and Body Mass Index. PLos One, 10(7), E0130903.

World Health Organization. (2018). Prevalence of Insufficient Physical Activity. Retrieved from http://www.who.int/gho/ncd/risk_factors/physical_activity_text/en/ 